\title{
Flexural Performance of Hybrid GFRP-Steel Reinforced Concrete Continuous Beams
}

\author{
Almahdi Mohamed Araba ${ }^{1}$, Ashraf. F. Ashour ${ }^{2}$
}

\section{ABSTRACT}

This paper presents the experimental results of five large-scale hybrid glass fiber reinforced polymer (GFRP)-steel reinforced concrete continuous beams compared with two concrete continuous beams reinforced with either steel or GFRP bars as reference beams. In addition, two simply supported concrete beams reinforced with hybrid GFRP/steel were tested. The amount of longitudinal GFRP, steel reinforcements and area of steel bars to GFRP bars were the main investigated parameter in this study. The experimental results showed that increasing the GFRP reinforcement ratio simultaneously at the sagging and hogging zones resulted in an increase in the load capacity, however, less ductile behaviour. On the other hand, increasing the steel reinforcement ratio at critical sections resulted in more ductile behaviour, however, less load capacity increase after yielding of steel.

The test results were compared with code equations and available theoretical models for predicting the beam load capacity and load-deflection response. It was concluded that Yoon's model reasonably predicted the deflection of the hybrid beams tested, whereas, the ACI.440.1R-15 equation underestimated the hybrid beam deflections. It was also shown that the load capacity prediction for hybrid reinforced concrete continuous beams based on a collapse mechanism with plastic hinges at mid-span and central support sections was reasonably close to the experimental failure load. 


\section{INTRODUCTION}

Deterioration, reduced serviceability and failure of concrete structures reinforced with steel bars are inevitably the most common consequences of corrosion of steel reinforcement. Hence, this phenomenon has become a major concern in the construction industry due to a substantial increase of maintenance and repair costs. The use of fibre reinforced polymer (FRP) as an alternative reinforcement in concrete structures has emerged as an innovative solution owing to their non-corrosive and non-magnetic properties, making them an ideal reinforcement for severe environments and situations where magnetic transparency is required. However, due to the low modulus of elasticity of FRP, there is a noticeable reduction in the flexural stiffness of concrete members reinforced with FRP bars. This reduction occurs after cracking, which in return, causes a substantial increase in deformation under service conditions [1].

Moreover, due to the linear-elastic behavior of FRP composite materials up to rupture, continuous concrete beams reinforced with FRP rebars generally exhibit less ability to redistribute stresses between critical sections compared to those reinforced with steel rebars [2-4]. As a result, a sudden failure is expected to occur with little or no warning. Therefore, there is a need for a new method of construction to avoid such problems; that is durable, cost effective, and exhibits some ductility. A number of methods have been suggested to improve ductility, including hybridization of different types of fibrous material [5-8] and combining steel reinforcement with composite materials to make a

rebar with an inner steel and an outer FRP [9-13]. These attempts were not practical to be implemented in the construction industry due to the high cost 
and complexity of manufacturing process. More practical solutions have been suggested such as; confinement of concrete in compression zone [14], addition of fibres to concrete [15-17] and use of a hybrid combination of FRP and steel re-bars [18-26]. Such hybrid reinforcement system shows improved serviceability and ductility, and enhancement of load-carrying capacity compared to traditional reinforcement $[19,21]$. In spite of the fact that the literature shows some research on simply supported beams reinforced with hybrid FRP and steel rebars [18-25], none of these research projects was carried out to investigate the structural behaviour and failure modes of multispan continuous hybrid reinforced concrete beams which are considerably different from those of simply supported ones. Therefore, concrete continuous beams are not well represented by statically determinate specimens tested in previous studies. For instance, the moment redistribution characteristics and the changes in the beam curvature from sagging to hogging do not exist in simply supported beams. Moreover, the majority of concrete structures in practice are multi-span continuous members.

This paper presents the experimental testing of five hybrid continuous concrete beams in comparison with traditional reinforced ones (either GFRP or steel bars). Two cases of hybrid reinforcement configuration were tested in comparison to the control beams. In the first case, while the amount of GFRP bars remained constant, the amount of steel reinforcement was increased. While in the second case, the area of GFRP bars was increased and the steel reinforcement remained constant. Crack widths, strains in tensile steel reinforcement, modes of failure, end support reaction, moment capacity and deflections were measured. The test results were then compared with the 
predictions of code equations and available theoretical models for load capacity and load-deflection response. The test results would contribute to future development of design guidelines for continuous concrete beams reinforced with hybrid GFRP-steel bars.

\section{EXPERIMENTAL PROGRAM}

\section{Geometrical and Dimensions of Test Specimens}

Three simple and seven continuous reinforced concrete beams were tested in flexure. All specimens tested were $200 \mathrm{~mm}$ in width and $300 \mathrm{~mm}$ in depth. The continuous beams comprised of two equal spans, each of $2600 \mathrm{~mm}$, while the simply supported beams had a span of $2600 \mathrm{~mm}$, as shown in Figs 1 and 2, respectively. The thickness of concrete cover to all top and bottom GFRP reinforcements was $30 \mathrm{~mm}$ and kept constant along the reinforcing bars.

Five continuous concrete beams were reinforced with a hybrid combination of both GFRP and steel re-bars at bottom mid spans and top over middle support region. In addition, two continuous concrete beams reinforced with either GFRP or steel bars, one simply supported beam reinforced with GFRP bars and two simply supported beams reinforced with hybrid GFRP/steel reinforcement were tested as control beams as shown in Figs 1 and 2, respectively. 

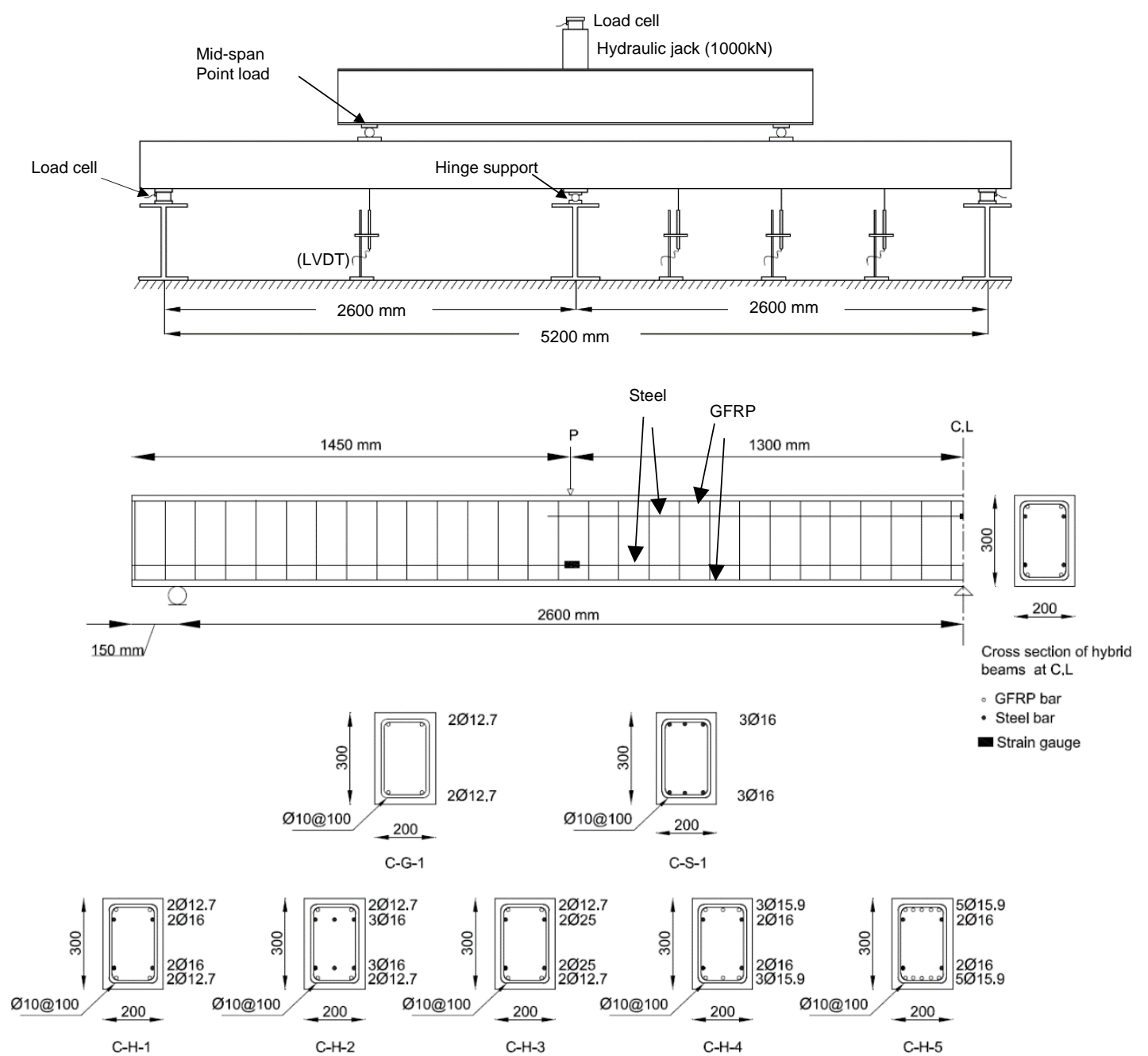

Figure 1. Experimental setup and details of continuous beams. 


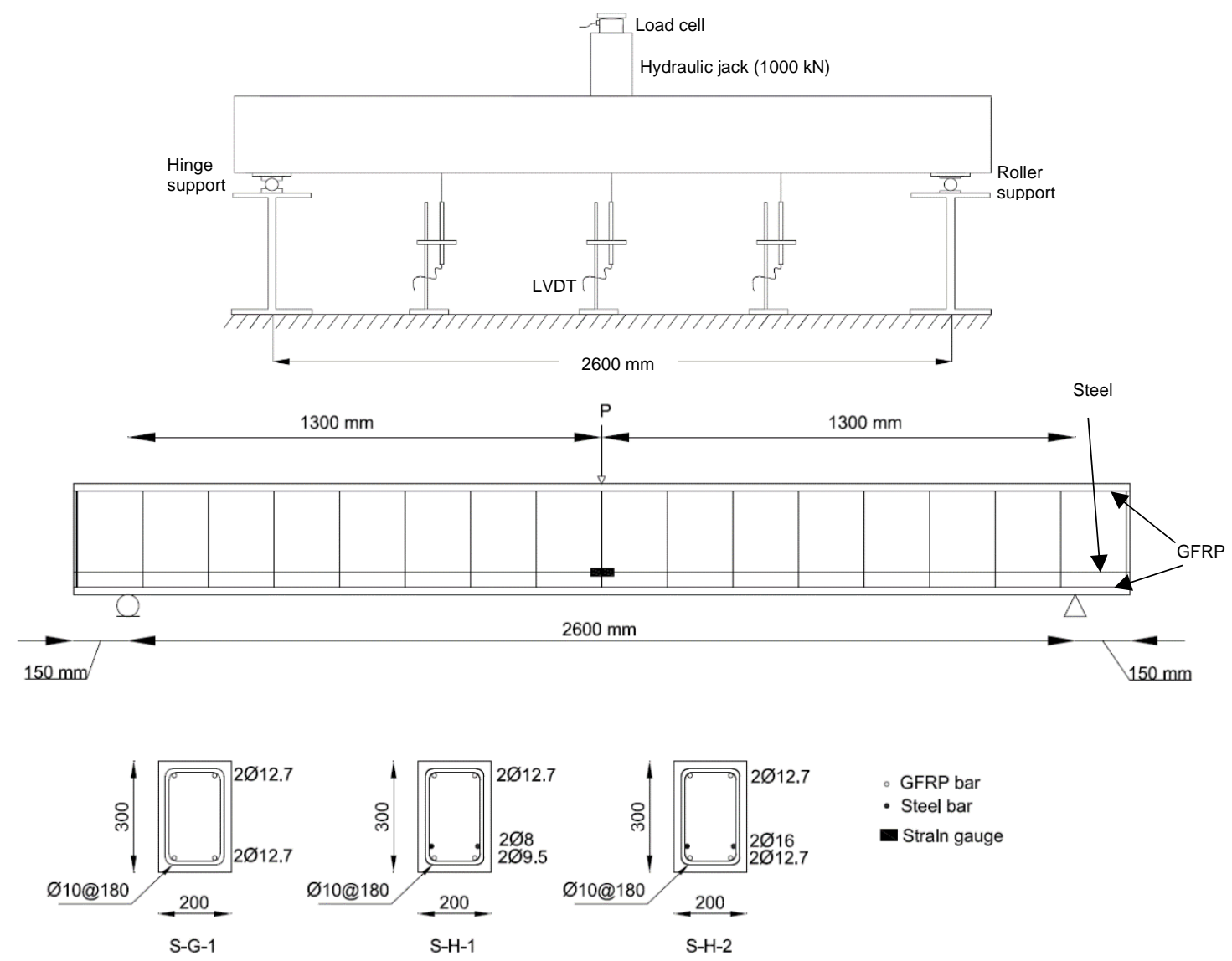

Figure 2. Experimental setup and details of simple beams.

Table 1 presents the reinforcement used in each beam tested. Each continuous beam had the same top and bottom reinforcement. The amount of GFRP reinforcement in the GFRP reinforced concrete continuous beam C-G1 was chosen to fail in compression (concrete crushing) at mid span and over support sections as recommended by ACl 440.1R-15 [1]. Therefore, it was reinforced with two GFRP bars of $12.7 \mathrm{~mm}$ diameter at the top and bottom layers. On the other hand, the steel-reinforcement ( 3 bars of $16 \mathrm{~mm}$. diameter) of the continuous beam C-S-1 was selected to achieve a tensile capacity of $330 \mathrm{kN}$, equivalent to that of the two GFRP of $12.7 \mathrm{~mm}$ diameter, used in beam C-G-1. The simply supported beam S-G-1 was reinforced with two GFRP bars of $12.7 \mathrm{~mm}$ diameter (over reinforced) similar to beam C-G-1. 
For the continuous beams with hybrid reinforcements, the design of hybrid GFRP-steel sections is based on the assumption that failure mode is governed by yielding of tensile steel reinforcing bars before rupture of GFRP bars or concrete crushing. The combination of GFRP and steel reinforcements are then chosen based on the criteria shown in Fig 3 , that identifies the failure modes of a hybrid section with the material properties given in Tables 1 and 2 [27]. The dotted and solid lines represent the boundaries of different flexural modes for cylinder compressive strength of concrete of $40 \mathrm{MPa}$ and $70 \mathrm{MPa}$, respectively. The hybrid GFRP/steel reinforcements were selected to investigate the influence of increasing one type of reinforcement ratio while the other reinforcement ratio is kept constant on the structural performance of the beams as summarized in Table 1. In addition, the effect of steel reinforcement area to GFRP reinforcement are is considered to take into account the effect of axial stiffness on the flexural behaviour. The hybrid reinforced concrete beams were reinforced with five different longitudinal reinforcement combinations. 


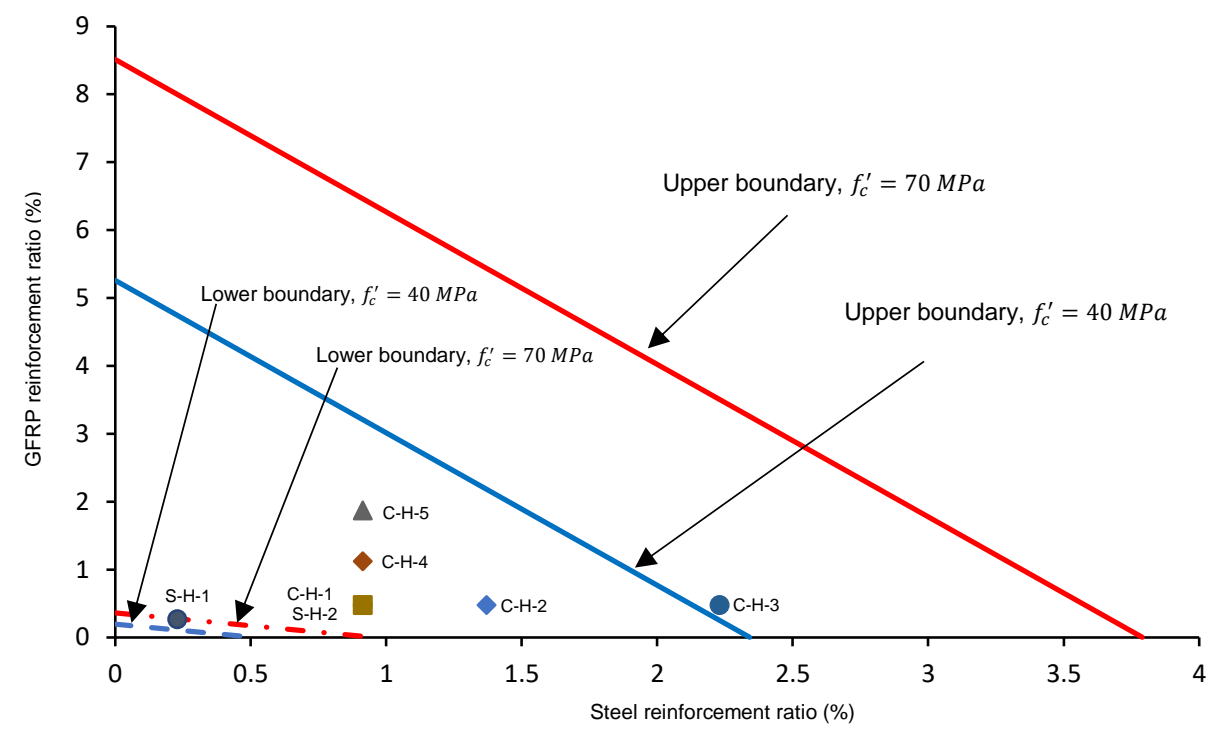

Figure 3. GFRP reinforcement ratio vs steel reinforcement ratio, indicating the different flexural failures

Beam C-H-1 was reinforced with two GFRP longitudinal bars of $12.7 \mathrm{~mm}$ diameter and two steel longitudinal bars of $16 \mathrm{~mm}$ diameter on the bottom and top sides. It is considered as a control hybrid continuous beam to measure the effect of increasing either steel or GFRP reinforcement. Beams C-H-2 and C$\mathrm{H}-3$ had the same GFRP reinforcement as that in $\mathrm{C}-\mathrm{H}-1$, but the amount of steel reinforcement was increased than that of $\mathrm{C}-\mathrm{H}-1$ as shown in Table 1. On the other hand, beams $\mathrm{C}-\mathrm{H}-4$ and $\mathrm{C}-\mathrm{H}-5$ had the same steel reinforcement as that in $\mathrm{C}-\mathrm{H}-1$, but the amount of GFRP reinforcement was increased.

The simply supported beams S-G-1, S-H-1 and $\mathrm{S}-\mathrm{H}-2$, were reinforced with two GFRP bars of $12.7 \mathrm{~mm}$ diameter (over reinforced), two GFRP bars of 9.5 $\mathrm{mm}$ diameter and two steel bars of $8 \mathrm{~mm}$ diameter, and two GFRP bars of 12.7 $\mathrm{mm}$ diameter and two steel bars of $16 \mathrm{~mm}$ diameter, respectively.

The bottom longitudinal steel bars were elevated, whereas the top longitudinal steel bars were lowered to increase the protecting concrete cover and, in 
return, improve the durability. The concrete cover to the centre of the bottom and top main steel bars was $80 \mathrm{~mm}$. All continuous and simply supported beams were provided with $10-\mathrm{mm}$ diameter steel stirrups spaced at $100 \mathrm{~mm}$ and $180 \mathrm{~mm}$, respectively, throughout the entire length to prevent shear failure. Although, the steel stirrups are more vulnerable to corrosion than longitudinal steel reinforcement due to their lower cover, they have been used in the test specimens as FRP stirrups are not yet widely available. In addition, from a performance point of view results showed that the performance of the GFRPreinforced beam provided with GFRP stirrups was similar to its counterpart reinforced with steel stirrups [28].

It should be mentioned that negative moment reinforcements were curtailed beyond the mid-span point load except those at top corners used as stirrup hangers along the beam span, whereas bottom bars continued throughout the beam length as shown in Fig 1. As for simply supported beams, bottom and top bars continued throughout the beam length as shown in Fig 2 .

The beam notation was defined according to the type of reinforcement and support system. The first letter in the notation indicates the type of supporting system, ' $C$ ' for continuous beams and ' $S$ ' for simply supported beams. The second letter corresponds to the type of reinforcement, either ' $S$ ', 'G' or ' $\mathrm{H}$ ' for steel, GFRP and hybrid GFRP/steel, respectively, followed by a number indicating the beam number.

\section{Material properties}

The GFRP bars used in this study had a sand-coated surface to enhance their bond with concrete and load transfer. The bars were made of continuous longitudinal fibers impregnated in a thermosetting vinyl-ester resin with a fibre 
content of $81 \%$ by weight (Pultrall Inc. 2015). Deformed steel bars were used in the flexural and shear reinforcement of the tested beams.

Tensile tests of reinforcing steel and GFRP specimens were conducted until rupture according to ACl.440.3R-04 [29]. Table 2 details the properties of the entire bar reinforcement used in the beams tested.

Ready-mix concrete of 20-mm maximum aggregate size was used to construct all test specimens. The concrete beams were cast in three deliveries of concrete (three groups): Group one consisted of C-S-1, C-G-1, C-H-1, C-H-2 and $\mathrm{C}-\mathrm{H}-3$, beams $\mathrm{C}-\mathrm{H}-4, \mathrm{C}-\mathrm{H}-5$ and $\mathrm{S}-\mathrm{G}-1$ formed group two, while beams $\mathrm{S}-$ $\mathrm{H}-1$ and $\mathrm{S}-\mathrm{H}-2$ were from group three. This explains the variation in concrete compressive strength of specimens. After concrete casting, all specimens were stored under the same condition and covered by polyethylene sheets to keep down moisture loss at all times during the period of curing until the day of testing. The average values of the cube compressive strength, $f_{c u}$, and splitting tensile strength, $f_{c t}$ (see Table 1) were obtained by testing three 100 $\mathrm{mm}$ cubes and three $150 \mathrm{~mm}$ diameter by $300 \mathrm{~mm}$ high cylinders immediately after testing of each specimen. In addition, two $100 \times 100 \times 500 \mathrm{~mm}$ prisms were also tested for each group of beams to obtain the modulus of rupture, $f_{r}$, as listed in Table 1. 
Table 1. Concrete properties and reinforcement details

\begin{tabular}{|c|c|c|c|c|c|c|c|c|c|}
\hline \multirow{3}{*}{$\begin{array}{l}\text { Beam } \\
\text { notation }\end{array}$} & \multirow{2}{*}{\multicolumn{2}{|c|}{$\begin{array}{c}\begin{array}{c}\text { Bottom bars at } \\
\text { mid-span }\end{array} \\
\text { Area }\left(\mathrm{mm}^{2}\right) \\
\end{array}$}} & \multirow{2}{*}{\multicolumn{2}{|c|}{$\begin{array}{c}\text { Top bars at } \\
\text { central support } \\
\text { Area }\left(\mathrm{mm}^{2}\right) \\
\end{array}$}} & \multicolumn{2}{|c|}{$\begin{array}{c}\text { Reinforcement } \\
\text { ratio }\end{array}$} & \multicolumn{3}{|c|}{ Concrete properties } \\
\hline & & & & & \multirow{2}{*}{$A_{s} / A_{f}$} & \multirow{2}{*}{$\mathrm{R}^{\mathrm{a}}$} & \multirow{2}{*}{$\begin{array}{c}f_{c u} \\
(M P a)\end{array}$} & \multirow{2}{*}{$\begin{array}{c}f_{c t} \\
(M P a)\end{array}$} & \multirow{2}{*}{$f_{r}(M P a)$} \\
\hline & $A_{s}$ & $A_{f}^{a}$ & $A_{s}$ & $A_{f}^{a}$ & & & & & \\
\hline C-S-1 & 603 & - & 603 & - & - & - & 50.5 & 2.8 & \\
\hline C-G-1 & - & 279 & - & 279 & - & - & 48.0 & 3.3 & \\
\hline $\mathrm{C}-\mathrm{H}-1$ & 402 & 279 & 402 & 279 & 1.4 & 5.30 & 50.7 & 3.1 & 3.3 \\
\hline $\mathrm{C}-\mathrm{H}-2$ & 603 & 279 & 603 & 279 & 2.2 & 7.90 & 54.0 & 2.7 & \\
\hline $\mathrm{C}-\mathrm{H}-3$ & 982 & 279 & 982 & 279 & 3.5 & 13.00 & 54.6 & 2.9 & \\
\hline $\mathrm{C}-\mathrm{H}-4$ & 402 & 660 & 402 & 660 & 0.6 & 2.20 & 70.6 & 3.6 & \\
\hline $\mathrm{C}-\mathrm{H}-5$ & 402 & 1100 & 402 & 1100 & 0.4 & 1.30 & 75.0 & 3.6 & 4.2 \\
\hline S-G-1 & - & 279 & - & 279 & - & - & 72.0 & 3.6 & \\
\hline $\mathrm{S}-\mathrm{H}-1$ & 100.5 & 170 & - & 279 & 0.6 & 2.2 & 63.2 & 3.4 & \\
\hline $\mathrm{S}-\mathrm{H}-2$ & 402 & 279 & - & 279 & 1.4 & 5.3 & 66.6 & 3.4 & 4.0 \\
\hline
\end{tabular}

Table 2. Properties of GFRP and steel reinforcements used in the tested beams

\begin{tabular}{|c|c|c|c|c|c|c|c|}
\hline \multirow{2}{*}{ Type of bars } & \multicolumn{2}{|c|}{$\begin{array}{l}\text { Bar size: } \\
\text { (mm) }\end{array}$} & \multirow{2}{*}{$\begin{array}{c}\text { Modulus } \\
\text { of } \\
\text { elasticity } \\
: \\
(\mathrm{GPa})\end{array}$} & \multirow{2}{*}{$\begin{array}{l}\text { Tensile } \\
\text { strengt } \\
\text { h: } \\
(\mathrm{MPa})\end{array}$} & \multirow{2}{*}{$\begin{array}{c}\text { Yield } \\
\text { strength } \\
\text { (MPa) }\end{array}$} & \multirow{2}{*}{$\begin{array}{l}\text { Rupture } \\
\text { strain }\end{array}$} & \multirow{2}{*}{$\begin{array}{l}\text { Yield } \\
\text { strain }\end{array}$} \\
\hline & Nominala & Measured & & & & & \\
\hline \multirow{3}{*}{$\begin{array}{l}\text { Longitudinal } \\
\text { GFRP }\end{array}$} & 9.50 & 10.40 & 55 & 1100 & $\mathrm{~N} / \mathrm{A}$ & 0.020 & $\mathrm{~N} / \mathrm{A}$ \\
\hline & 12.70 & 13.33 & 55 & 1200 & $\mathrm{~N} / \mathrm{A}$ & 0.021 & $\mathrm{~N} / \mathrm{A}$ \\
\hline & 15.90 & 16.74 & 55 & 1200 & $\mathrm{~N} / \mathrm{A}$ & 0.021 & $\mathrm{~N} / \mathrm{A}$ \\
\hline \multirow{3}{*}{$\begin{array}{l}\text { Longitudinal } \\
\text { Steel }\end{array}$} & 8 & - & 200 & $\mathrm{~N} / \mathrm{A}$ & 580 & - & 0.0029 \\
\hline & 16 & - & 200 & $\mathrm{~N} / \mathrm{A}$ & 580 & - & 0.0029 \\
\hline & 25 & - & 200 & $\mathrm{~N} / \mathrm{A}$ & 580 & - & 0.0029 \\
\hline Steel stirrups & 10 & - & 200 & $\mathrm{~N} / \mathrm{A}$ & 580 & - & 0.0029 \\
\hline
\end{tabular}

\section{Test rig and instrumentation}

Each continuous reinforced concrete beam comprised of two equal spans supported on two end rollers and one middle hinge support. Each span was loaded at its mid-point as shown in Figs 1 and 2 via a hydraulic ram and independent steel reaction frame, which was bolted to the strong floor of the laboratory. Three load cells were utilised to measure the reactions at the two 
end supports and the main applied load from the hydraulic ram. Moreover, each continuous beam was instrumented with seven linear variable differential transducer (LVDTs) to measure the deflections at different locations as shown in Fig 1. Two LVDTs at the two mid-spans of continuous beams were used to record the vertical movement of each specimen. Additional two LVDTs were located at equal spacing of $L / 4$ on one span of the continuous beams to measure the deflections at these locations, where $L$ is the span length. The last three additional LVDTs were installed at the end and middle supports to measure any movement at supports. Three electrical strain gauges of $5 \mathrm{~mm}$ length were also mounted on the tensile longitudinal steel bars at mid spans and internal support to monitor the strain variation during loading. All load cells, LVDTs and strain gauges readings were automatically registered at each load increment using a data logger.

\section{RESULTS AND DISCUSSION}

\section{Crack propagation and reinforcement strains}

Crack propagation was monitored and manually marked throughout the beams testing. The crack patterns in the continuous reinforced concrete beams at failure were sketched in Fig. 4. The first visible cracking load of each beam tested is presented in Table 3. Generally, cracks were initially observed in the maximum moment regions below the point loads and over the internal support but propagated towards the compressed concrete zone with the load increase. At later stage of loading, more cracks appeared outside the maximum moment regions along the beams as shown in Fig. 4. The concrete beam reinforced with only steel bars exhibited a higher first cracking load than that reinforced with only GFRP bars due to the higher axial stiffness of steel bars than that of 
GFRP bars. On the other hand, the first crack of hybrid GFRP/steel beams occurred at a higher load than that of the steel beam C-S-1, except hybrid beam $\mathrm{C}-\mathrm{H}-1$. This is attributed to the fact that the axial stiffness $(E A)$ of the provided hybrid reinforcement at critical sections was higher than that of beam C-S-1. It is important to mention that not only the axial stiffness of specimens affected the cracking load, but also concrete compressive strength which affects the tensile strength of concrete as can be seen by comparing between beams $\mathrm{C}-\mathrm{H}-3$ and $\mathrm{C}-\mathrm{H}-5$. The crack lengths in the hybrid specimens and steel beam C-S-1 were smaller in comparison to that in GFRP beam C-G-1. This indicates that the presence of steel bars in hybrid beams can restrain the fast and deep propagation of cracks observed in the GFRP reinforced concrete beam. In addition, for beams with hybrid reinforcement, the crack spacing is lower and the number of cracks is higher than that in the GFRP beam as shown in Fig. 4. As the load increased, shear stresses had a profound effect and led to inclined cracks in beams $\mathrm{C}-\mathrm{H}-2, \mathrm{C}-\mathrm{H}-4$ and $\mathrm{C}-\mathrm{H}-5$. These cracks diagonally propagated towards the vicinity of load points on the compressive side of these beams. However, beam $\mathrm{C}-\mathrm{H}-3$ exhibited a major horizontal crack in compression zone of sagging section at later stage of loading (near to failure) followed by a diagonal crack towards the intermediate support. Horizontal cracks were observed in Beams S-G-1 and S-H-1 at the bottom reinforcement level indicating deboning between GFRP bars and concrete. This can be attributed to the high deformation experienced by the aforementioned beams, which led to the slippage between GFRP bars and surrounding concrete. 


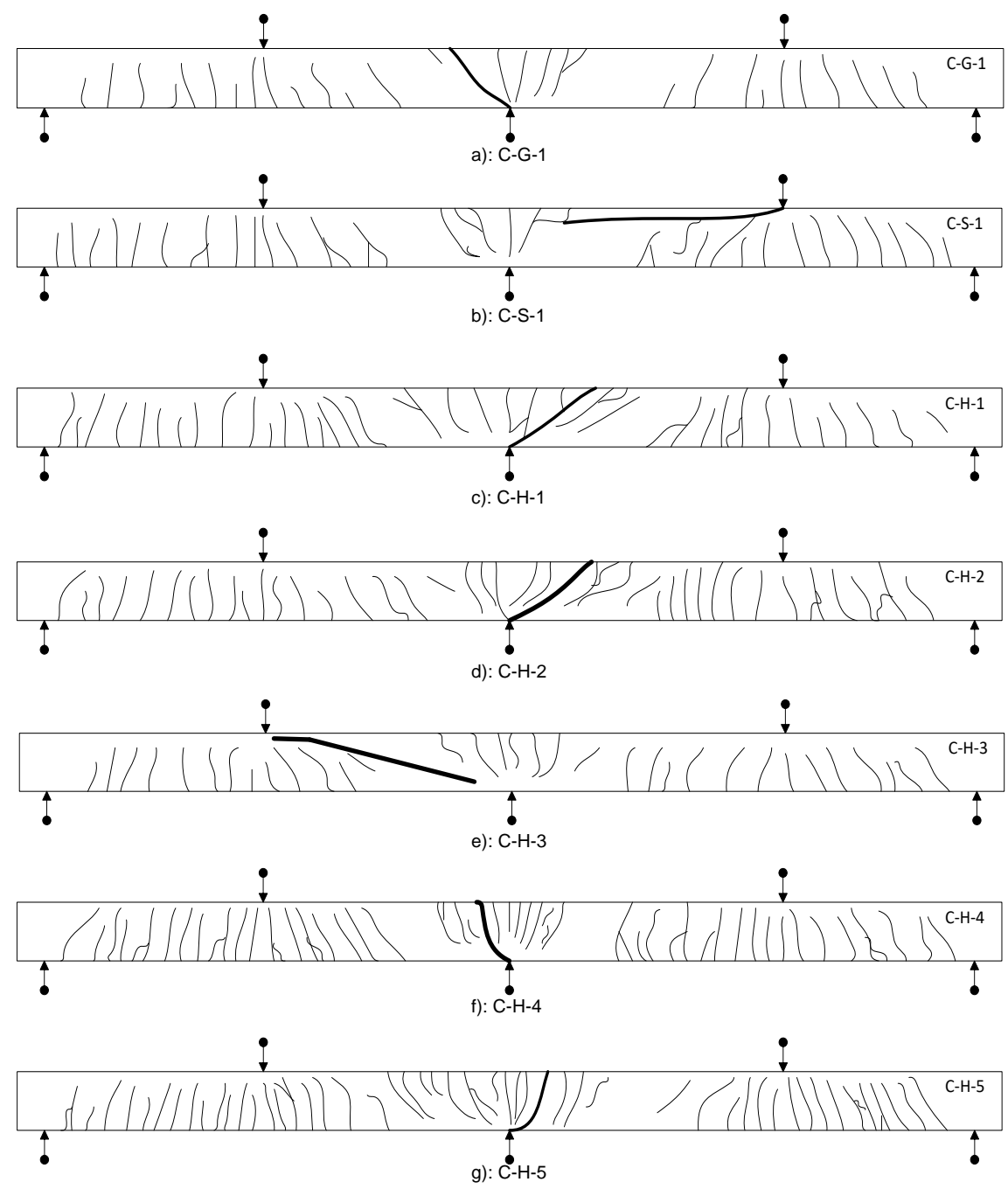

Figure 4. Crack patterns at failure of continuous concrete beams tested 
Table 3. First cracking and total experimental failure loads of beams tested

\begin{tabular}{|c|c|c|c|c|}
\hline \multirow{2}{*}{$\begin{array}{l}\text { Beam } \\
\text { notation }\end{array}$} & \multicolumn{2}{|c|}{$\begin{array}{l}\text { First cracking loads } \\
\qquad(k N)\end{array}$} & \multirow{2}{*}{$\begin{array}{c}\text { Failure } \\
\operatorname{loads}(k N)\end{array}$} & \multirow[t]{2}{*}{ Observed failure mode } \\
\hline & Sagging & Hogging & & \\
\hline C-S-1 & 47 & 45 & 511 & $\begin{array}{l}\text { Flexure-tension failure at both mid-span and } \\
\text { middle support }\end{array}$ \\
\hline C-G-1 & 33 & 30 & 309 & Concrete crushing \\
\hline $\mathrm{C}-\mathrm{H}-1$ & 43 & 40 & 465 & $\begin{array}{l}\text { Flexure-tension failure at both mid-span and } \\
\text { middle support }\end{array}$ \\
\hline $\mathrm{C}-\mathrm{H}-2$ & 52 & 50 & 571 & Flexure-shear failure at middle support \\
\hline $\mathrm{C}-\mathrm{H}-3$ & 57 & 55 & 589 & $\begin{array}{l}\text { Flexure-tension failure at both mid-span and } \\
\text { middle support }\end{array}$ \\
\hline $\mathrm{C}-\mathrm{H}-4$ & 63 & 60 & 665 & Flexure-shear failure at middle support \\
\hline $\mathrm{C}-\mathrm{H}-5$ & 68 & 65 & 781 & Flexure-shear failure at middle support \\
\hline S-G-1 & 10 & $\mathrm{~N} / \mathrm{A}$ & 118 & GFRP bar rupture at mid span \\
\hline $\mathrm{S}-\mathrm{H}-1$ & 9 & $\mathrm{~N} / \mathrm{A}$ & 94 & Flexure-tension failure at mid-span \\
\hline $\mathrm{S}-\mathrm{H}-2$ & 15 & $\mathrm{~N} / \mathrm{A}$ & 169 & Flexure-tension failure at mid-span \\
\hline
\end{tabular}

Note that the first cracking and failure loads are the total loads acting on each beam tested, i.e. the sum of the two mid-span point loads in case of continuous beams and the mid-span point load in case of simply supported ones.

The relation between the total applied load and the width of flexural cracks at the sagging moment region is shown in Figs 5 and 6 . The results were obtained by recording the width of cracks using high quality digital cameras. Two cameras were used to capture the flexural crack of sagging zone at mid-spans. The images of cracks at mid-spans were processed by Image-Pro Plus software version 6.0. As for continuous concrete beams, only one side flexural crack is presented in Fig 5 due to the similarity in crack widths between the two spans. It can be observed that increasing the amount of longitudinal GFRP or steel re-bars had a clear effect on flexural crack widths. However, the addition of steel reinforcement had a more significant effect on reducing the crack width than GFRP reinforcement. To meet the serviceability limit requirements, the crack width in sections reinforced with FRP should not exceed $0.4 \mathrm{~mm}$ for members subjected to aggressive environment, and 0.7 $\mathrm{mm}$ for other members [1]. For comparison purposes, the crack control provisions for steel reinforcement in $\mathrm{ACl} 318-14$ [30] corresponds to a 
maximum crack width that varies approximately between $0.46-0.56 \mathrm{~mm}$. It is clear that all hybrid beams did not exceed the max crack width limit at service load (67\% ultimate load). Moreover, beams $\mathrm{C}-\mathrm{H}-3$ and $\mathrm{C}-\mathrm{H}-5$ even did not exceed the low limit specified for steel reinforcement. This clearly shows the benefit of using such hybrid reinforcement where serviceability limits requirements could be achieved with less reinforcement ratio and in return less cost in comparison with using only FRP bars as internal reinforcement.

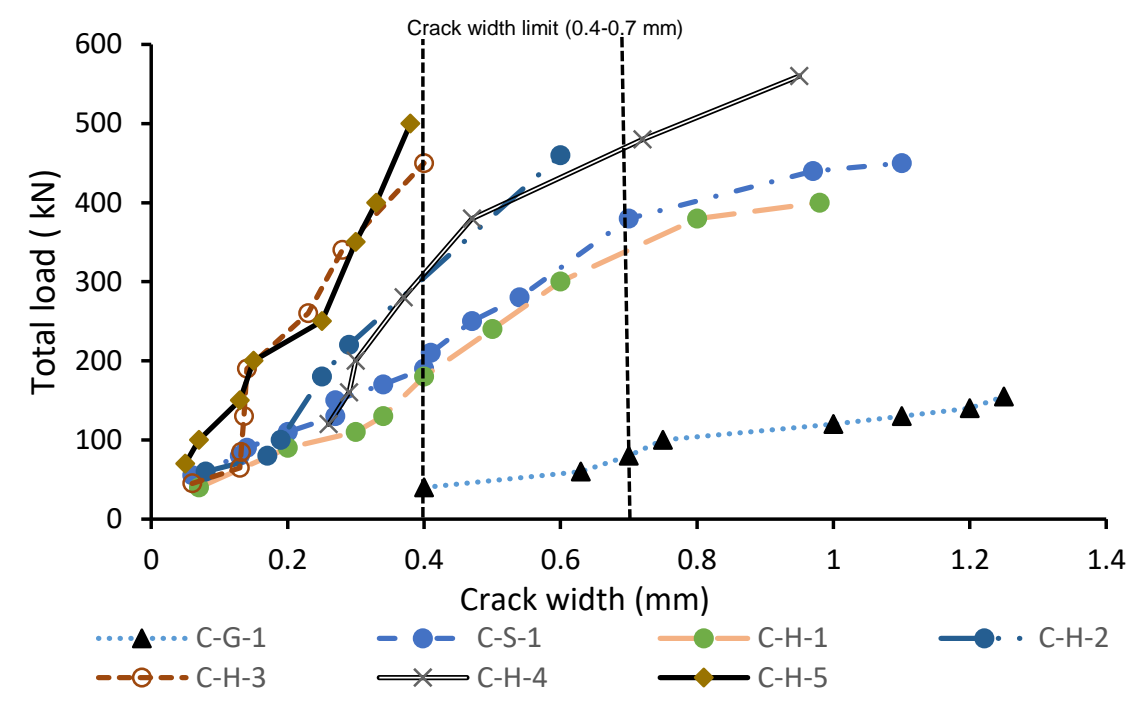

Figure 5. Mid-span crack width of continuous beams tested

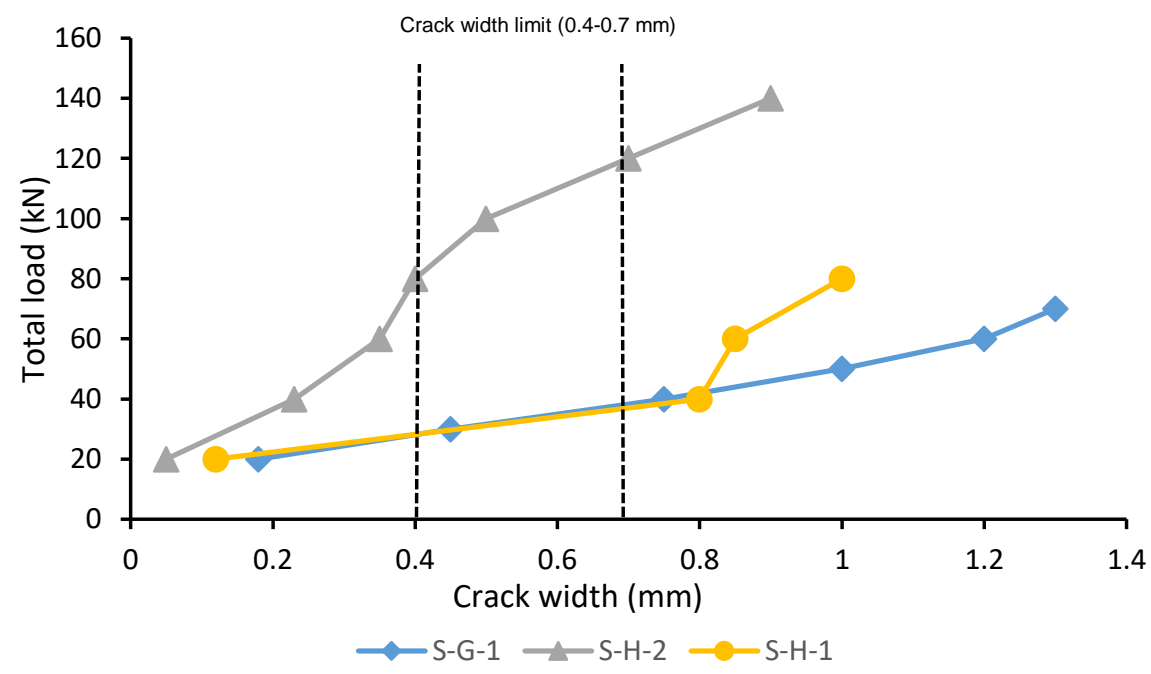

Figure 6. Mid-span crack width of simply supported beams tested 
Figures 7 and 8 present the tensile strains in the bottom steel reinforcement at the mid-span and top steel reinforcement at the internal support against the total applied load for the continuous beams tested, respectively. After the first crack, the steel strains increased at an almost constant rate until yielding occurred at either the sagging or hogging region. In general, all hybrid GFRP/steel beams exhibited their first steel yielding in the hogging regions as shown in Figs. 7 and 8 as the hogging region is exposed to higher stresses than sagging zone for the same total applied load. On the other hand, for specimen C-S-1, yielding of tensile steel in the sagging and hogging regions occurred at very similar loads as shown in Figs. 7 and 8, respectively. This is attributed to the difference in flexural rigidity between the mid-span and oversupport sections as the steel reinforcement ratio in compression zone at hogging region is higher than that of sagging region. Generally, the results show that increasing either GFRP reinforcement ratio $(\mathrm{C}-\mathrm{H}-5)$ or steel reinforcement ratio $(\mathrm{C}-\mathrm{H}-3)$ delayed the yielding of tensile steel, hence increased the yielding and ultimate loads of beams tested. In specimen $\mathrm{C}-\mathrm{H}$ 4 , the experimental tensile steel strain response at hogging zone, was not recorded due to malfunction of the corresponding strain gauges. 


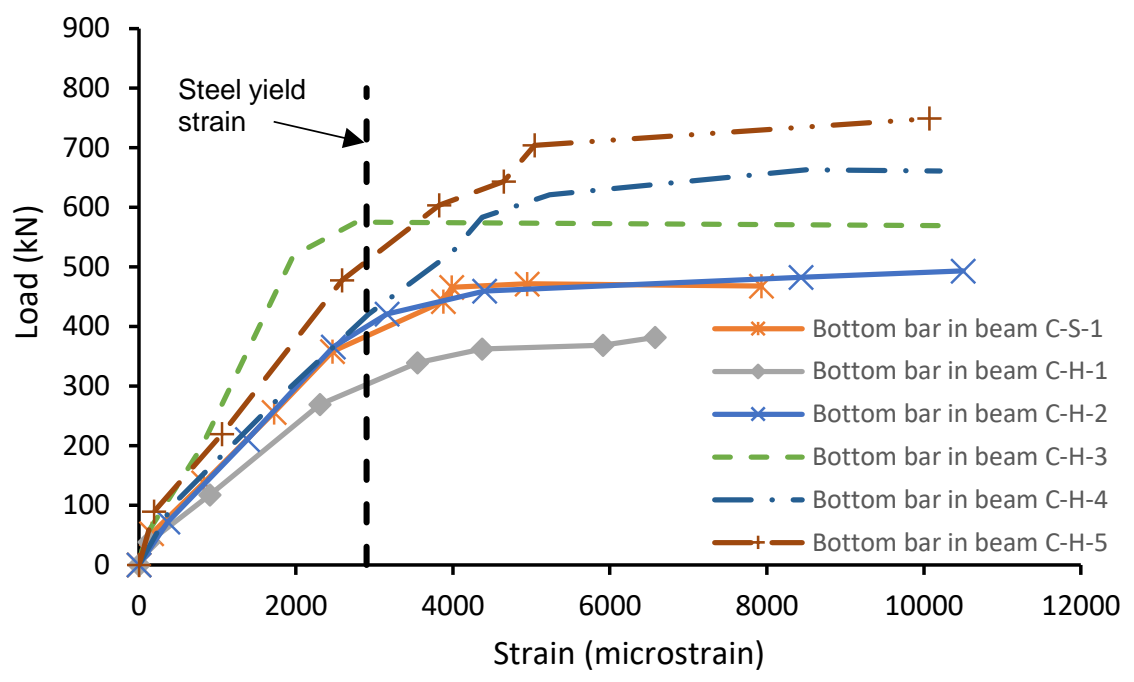

Figure 7. Total applied load versus tensile steel strains at mid-span of continuous beams tested

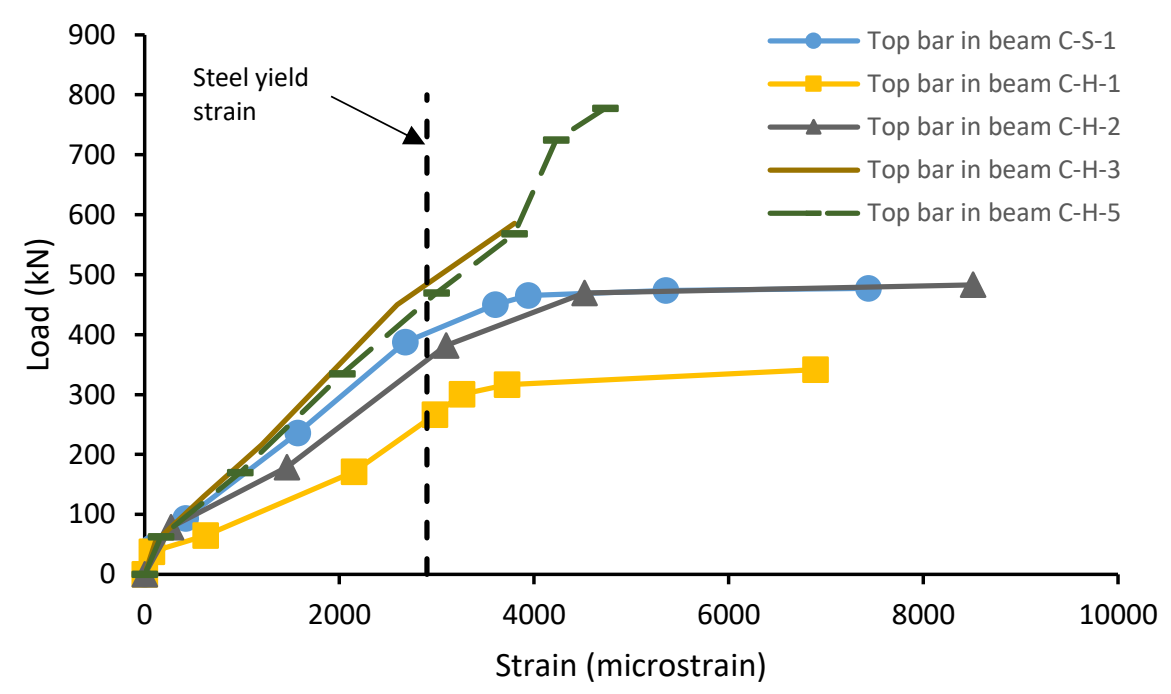

Figure 8. Total applied load versus tensile steel strains at middle support of continuous beams tested 


\section{Failure modes}

Four different failure modes were observed in the experimental tests as shown in Fig. 9, summarized in Table 3 and explained below.

\section{Mode 1: Conventional ductile flexural failure}

This mode was demonstrated by the continuous concrete beam C-S-1, that reinforced only with steel bars. The failure of C-S-1 eventually occurred due to yielding of tensile steel reinforcement at both middle support and mid-span sections followed by concrete crushing as shown in Fig. 9-A.

\section{Mode 2: Bar rupture}

This mode was illustrated by beams S-G-1 and S-H-1 as shown in Figs. 9-B and 9-C. As for beam S-G-1, it was designed to have reinforcement ratio of GFRP at the bottom layer higher than the balanced reinforcement ratio $\left(\rho_{b}\right)$. Owing to the reinforcement ratio, it was expected that strains in GFRP reinforcement would not reach its rupture limit before the full exhaustion of the ultimate concrete strain. Such anticipation has not been exhibited by beam SG-1. This is mainly due to the difference between the assumed concrete compressive strength $\left(f_{c u}=40 \mathrm{MPa}\right)$ that used to find the balanced reinforcement ratio $\left(\rho_{b}\right)$ and the actual compressive strength $\left(f_{c u}=72 \mathrm{MPa}\right)$ of concrete used in casting such beam. This difference resulted in increasing the balanced reinforcement ratio from 0.17 to 0.32 .

For beam S-H-1, rupture of GFRP bars occurred post the yield of steel reinforcement. The beam experienced this mode of failure due to the concrete compressive strength increase as the concrete section was mainly designed for compressive strength $\left(f_{c u}=40 \mathrm{MPa}\right)$. This increase resulted in change of 
the failure mode from steel yielding before concrete crushing to GFRP rupture before concrete crushing as shown in Fig. 3 .

\section{Mode 3: Yielding of steel reinforcement followed by crushing of concrete} Hybrid beams $\mathrm{C}-\mathrm{H}-1, \mathrm{C}-\mathrm{H}-3$ and $\mathrm{S}-\mathrm{H}-2$ exhibited this mode of failure as shown in Figs 9-D, 9-F and 9-J. The failure of beam $\mathrm{C}-\mathrm{H}-1$ was in a ductile manner due to crushing of concrete in the compressive zone after yielding of steel bars. The failure in beam $\mathrm{C}-\mathrm{H}-3$ was compression failure at both sagging and hogging regions, followed by a major horizontal crack propagated towards the compression side of the middle support, causing a complete loss of load capacity of beam $\mathrm{C}-\mathrm{H}-3$. The behavior indicated enhanced shear resistance of the beam compared with the tested beams failed in shear. This is due to the highest axial stiffness (EA) of the beam which increased the dowel action component in the shear capacity and, consequently, the shear capacity. Failure of specimen $\mathrm{S}-\mathrm{H}-2$ was initiated by crushing of concrete at sagging zone after yielding of the steel reinforcement took place in the tension zone.

\section{Mode 4: Concrete crushing combined with shear failure}

This type of failure was observed in hybrid beams C-H-2, C-H-4, C-H-5 and GFRP beam C-G-1. The presence of high reinforcement ratio in compressive zone at middle support sections of beams $\mathrm{C}-\mathrm{H}-2, \mathrm{C}-\mathrm{H}-4$ and $\mathrm{C}-\mathrm{H}-5$ increased the compression resistance of the failed section. This might result in delaying concrete crushing strain which in return leads to loss of the section's expected flexural capacity. Such increase in compression force allowed the shear force to have a profound effect on the failure process as shown in Figs.9-E, 9-G and $9-\mathrm{H}$, respectively. It seems that the dowel action component was lower than 
that in beam $\mathrm{C}-\mathrm{H}-3$ due to the fact that the axial stiffness ratios of beams $\mathrm{C}-\mathrm{H}-$ 2, $\mathrm{C}-\mathrm{H}-4$ and $\mathrm{C}-\mathrm{H}-5$ are much lower than that of $\mathrm{C}-\mathrm{H}-3$ as shown in Table 1. Beam C-G-1 which was reinforced with an over reinforcement ratio of GFRP bars at the bottom and top layers experienced this mode of failure (see Fig. 9I). At a late stage of loading, wide cracks appeared over the intermediate support section, indicating bond-slip between GFRP bars and concrete. A diagonal shear crack emerged immediately after the flexural concrete crushing at the middle support region.
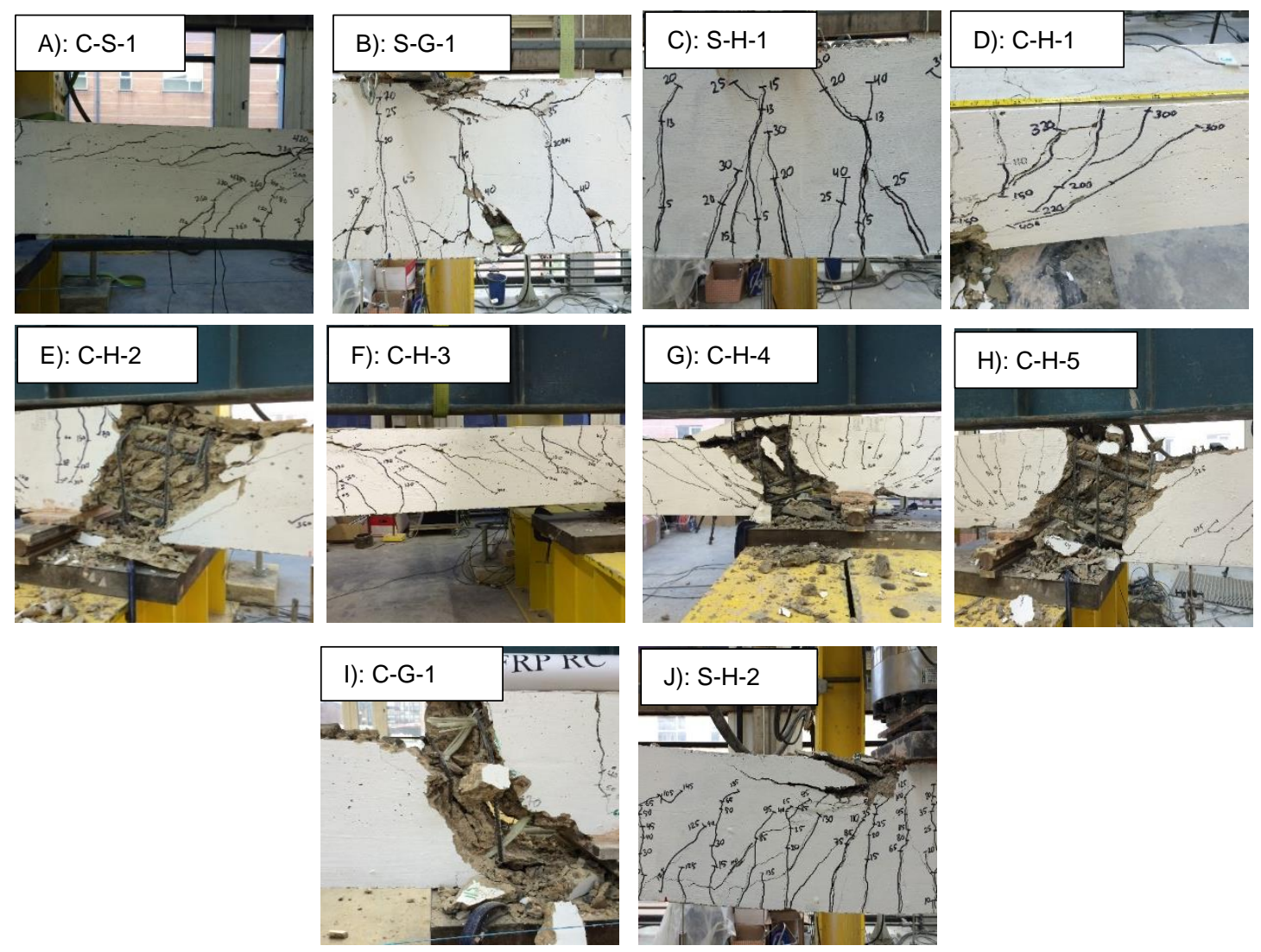

Figure 9. Failure modes of tested beams

\section{Load capacity}

Table 3 presents the failure loads of the beams tested. The failure loads of simply supported beams S-G-1 and S-H-2, respectively, were around $77 \%$ and 
$73 \%$ of the total failure loads of beams $\mathrm{C}-\mathrm{G}-1$ and $\mathrm{C}-\mathrm{H}-1$, respectively. This comparison between the failure loads of the simply supported beams S-G-1 and $\mathrm{S}-\mathrm{H}-2$; and that of the continuous hybrid $\mathrm{C}-\mathrm{G}-1$ and $\mathrm{C}-\mathrm{H}-1$ beams is due to the fact that each compared set of beams were reinforced with the same area of reinforcement. In comparison with beam $\mathrm{C}-\mathrm{H}-1$, beam $\mathrm{C}-\mathrm{H}-5$ that was reinforced with higher reinforcement ratio of GFRP bars tolerated more loads than beam $\mathrm{C}-\mathrm{H}-3$ that was reinforced with higher reinforcement of steel bars. This is attributed to the fact that GFRP bars play an important role to resist loading after yielding of steel reinforcement. In addition, the high compressive strength of beam C-H-5 contributed in load capacity increase. It also shows that load capacity increase is not dependent on the axial stiffness as the axial stiffness of $\mathrm{C}-\mathrm{H}-3$ is much higher than that of beam $\mathrm{C}-\mathrm{H}-5$. The results show that the load capacities of hybrid reinforced concrete continuous beams $\mathrm{C}-\mathrm{H}$ 2, $\mathrm{C}-\mathrm{H}-3, \mathrm{C}-\mathrm{H}-4$ and $\mathrm{C}-\mathrm{H}-5$ were, respectively, around 1.2, 1.26, 1.4 and 1.7 times that of the control beam $\mathrm{C}-\mathrm{H}-1$. This confirms that GFRP reinforcement is mainly responsible for enhancement of load capacity. Although the steel reinforcement ratio used to reinforce the critical sections of beam C-S-1 had similar strength of that used in beam C-G-1, beam C-S-1 exhibited a higher load capacity than that of beam reinforced with pure GFRP bars due to the large deformation resulting from the lower modulus of elasticity of GFRP.

\section{Load deflection response}

The relationship between the total applied load, $2 P$ and the recorded deflection at mid-span is shown in Fig. 10. There was no noticeable measured movement at the end and middle supports; therefore, not presented. Due to the similarity in the recorded vertical movement in the two spans of each beam, only one 
side mid-span deflection is presented. In Appendix A (Figure A.1), the deflections of the two mid-spans of two example beams, C-S-1 and C-H-3, are shown to emphasise that the symmetrical behaviour of the beams tested about the middle support extended up to the beam failure. All beams demonstrated linear load-deflection behaviour up to the cracking load. After the linear phase is reached its limit by concrete cracking, the beam stiffness is controlled by reinforcing bars which play a significant role in post cracking stage. However, there is a remarkable variation between tested beams in terms of reduction in stiffness, which resulted in the difference in cracking behaviour among tested beams. This is mainly due to the difference in reinforcement ratios used to reinforce concrete sections. The flexural stiffness after cracking is the highest for steel, followed by hybrid GFRP/steel with high reinforcement ratio, then hybrid GFRP/steel beams with low reinforcement ratio, followed by pure GFRP beam. It could be noticed that the load-deflection curves of hybrid-beams showed three different regions as follows; pre-cracking, post cracking, and yielding of steel. Whereas the GFRP beam exhibited bilinear curve in both uncracked and cracked stages. For hybrid GFRP/steel reinforced concrete beams, yielding of tensile steel reinforcement further reduces the beam stiffness to a similar level of pure GFRP beam stiffness. While the stiffness of hybrid GFRP/steel reinforced concrete beams C-H-1, C-H-2 and $\mathrm{C}-\mathrm{H}-4$ lies between these of their counterpart steel and GFRP reinforced concrete beams, the flexural rigidity of beams $\mathrm{C}-\mathrm{H}-3$ and $\mathrm{C}-\mathrm{H}-5$ is similar to that of beam C-S-1 up to the yielding load of steel control beam. Overall, the amount of GFRP and steel reinforcements used is a key factor in enhancing the flexural stiffness and, consequently, reducing deflections of the beams tested. As seen 
in Fig. 10, the stiffness of hybrid beams increased with either the increase of steel or GFRP reinforcement after the first cracking; the higher the ratio of hybrid reinforcement, the higher the stiffness. On the other hand, due to the elastic and brittle nature of GFRP reinforcement, the ductility of the hybrid beam specimens reinforced with larger GFRP reinforcement ratio was reduced as shown in Fig. 10. It is important to mention that this result could be beneficial for establishing a guide line to determine a suitable reinforcement ratio for hybrid GFRP/steel reinforced concrete beams, so that the achieved stiffness behaviour of hybrid beams can be according to the serviceability limit state requirements. The allowable deflection according to Canadian Standard Association (CSA) [31] ranges from $5.5-15 \mathrm{~mm}(\mathrm{~L} / 480-\mathrm{L} / 180$, where $\mathrm{L}$ is the beam span) based on the type and function of the structure. It can be noticed that the maximum deflections corresponding to the calculated service loads for hybrid beams $\mathrm{C}-\mathrm{H}-1, \mathrm{C}-\mathrm{H}-2$ and $\mathrm{C}-\mathrm{H}-3$ were $5,5.4,4.5 \mathrm{~mm}$, respectively, while hybrid beams $\mathrm{C}-\mathrm{H}-4$ and $\mathrm{C}-\mathrm{H}-5$ did not satisfy the low serviceability limit for certain structural applications in which the deflections corresponding to the service loads were 6.5 and $6.3 \mathrm{~mm}$, respectively.

In all hybrid beams tested, the presence of steel reinforcement had a profound effect on enhancement of the beam stiffness and load capacity after cracking. While GFRP bars showed an important role in resisting load after yielding of steel. An improvement in terms of deformability and ductility can also be observed for hybrid beams in comparison with the C-G-1 and C-S-1 reference beams. 


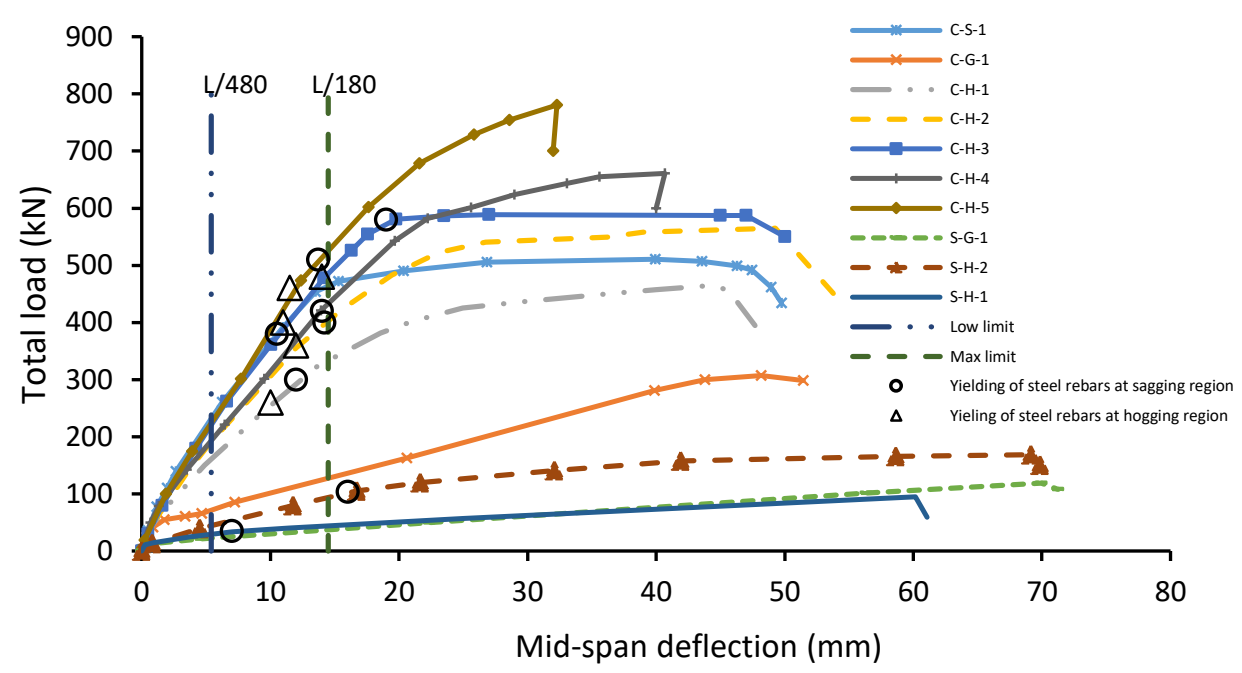

Figure 10. Load-deflection response of the tested beams

\section{Redistribution of support reactions}

Figure 11 shows the load transferred to the end support against the total applied load for each continuous beam tested. To assess the amount of load redistribution, the calculated end support reaction obtained from elastic analysis, was also plotted in Fig. 11. As expected, before concrete cracking, the measured end support reaction of all continuous beams was very close to that obtained from the elastic analysis as shown in Fig. 12. Similar load redistribution behaviour was observed for all beams. Due to the brittle behaviour of GFRP bars and ductile behaviour of steel bars, it was expected that distinctive load redistribution would be shown by beam C-S-1 in comparison to beam C-G-1 reinforced with only GFRP bars. As can be seen in Figs. 11 and 12, such anticipation has not been exhibited by beam C-S-1. This is accredited to the small difference between the sagging and hogging moments produced by the loading system used in the experiments; and the 
similar amount of steel reinforcement (three bars of $16 \mathrm{~mm}$ diameter) at the sagging and hogging regions of the steel reinforced concrete beam tested. As the amount was the same, strains in the top and bottom bars were similar and consequently, the yielding point for the top and bottom steel reinforcement was near enough to be compatible as shown in Figs. 7 and 8.

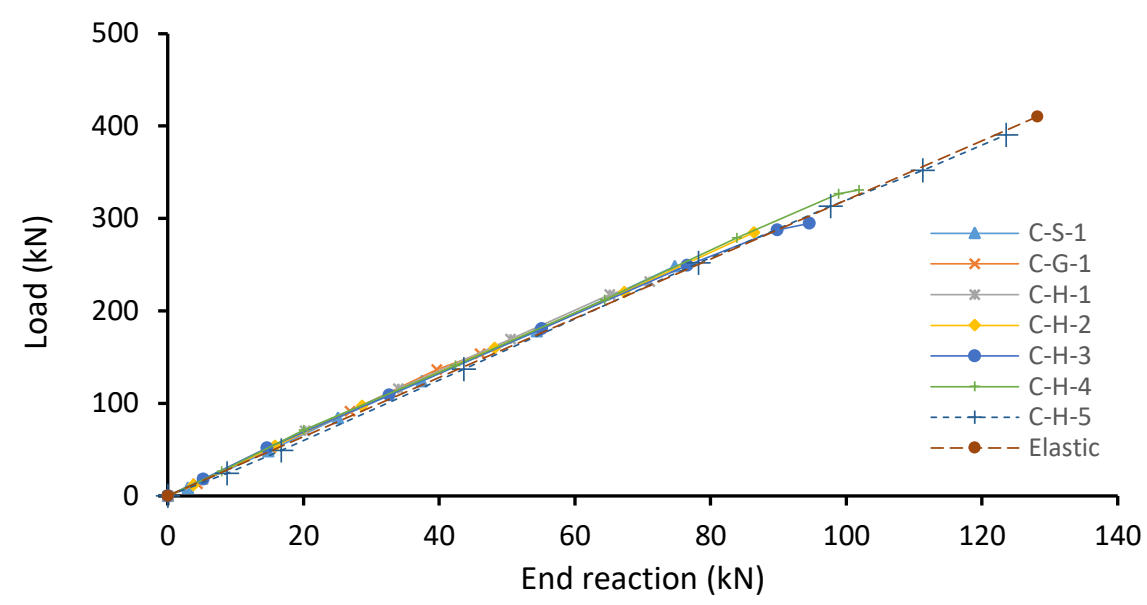

Figure 11. Load-end reactions relationship for the tested beams

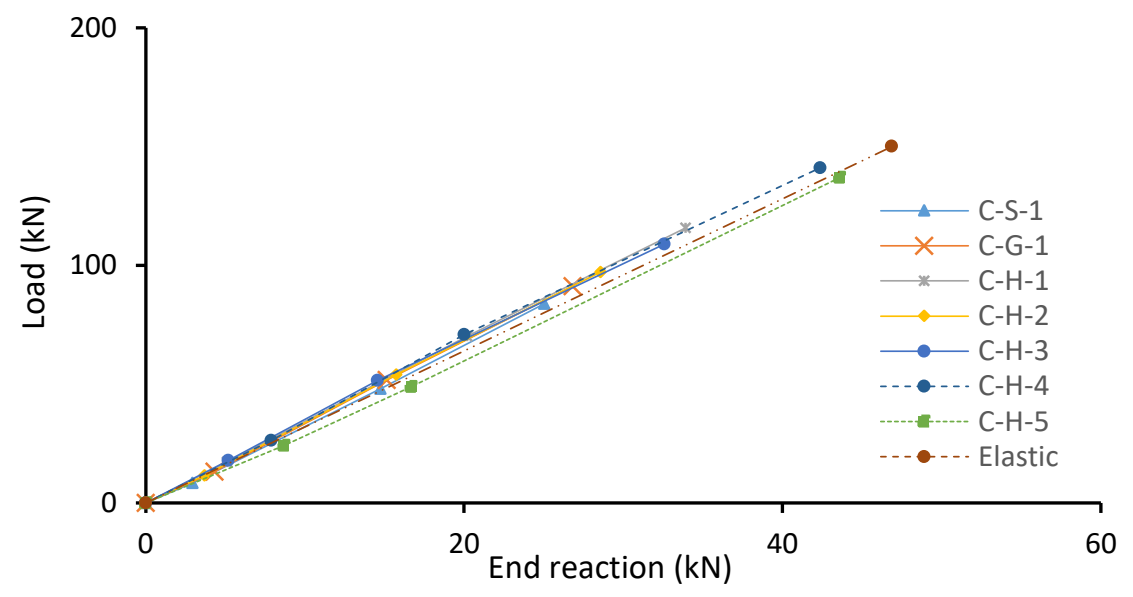

(a) 


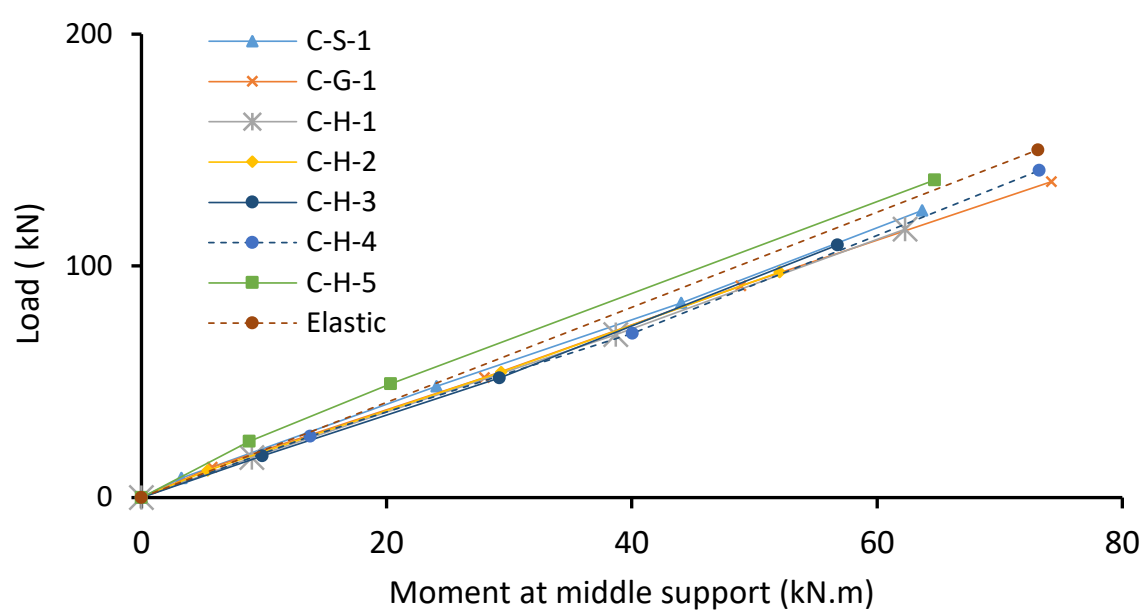

(b)

Figure 12. (a) End reactions - loads below $180 \mathrm{kN}$ relationship for the tested beams, (b) Hogging moment - loads below $180 \mathrm{kN}$ relationship for the tested beams

All continuous hybrid GFRP/steel reinforced concrete beams tested exhibited a similar trend of end support reactions. They failed, however, at different loads. The hybrid beams tested showed similar limited moment redistribution behaviour to beam C-S-1. For example, the maximum recorded end reaction of beam $\mathrm{C}-\mathrm{H}-1$ corresponding to the failure load, $P=232.4 \mathrm{kN}$, was around $71 \mathrm{kN}$. While the maximum calculated (based on elastic analysis) end reaction was $75 \mathrm{kN}$. Therefore, as shown in Fig 13, the bending moment at mid-span section, calculated from the measured end support reaction of beam $\mathrm{C}-\mathrm{H}-1$, was $92.3 \mathrm{kNm}$, which represents $97.5 \%$ of the calculated elastic moment of $94.5 \mathrm{kNm}$ at the failure load $P=232.4 \mathrm{kN}$. This would be mainly attributed to the same reinforcement ratio at the top and the bottom along the beam length. 

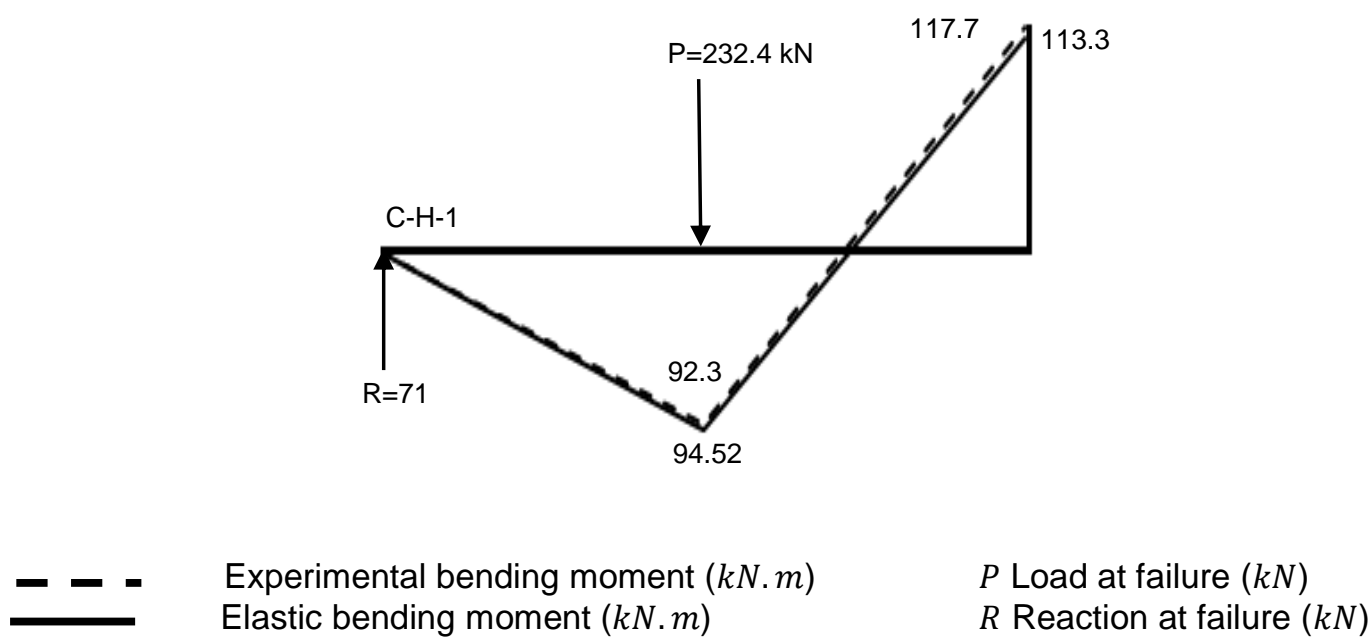

Figure 13. Actual versus elastic bending moment at failure

\section{Failure load and moment predictions}

The predicted moment capacities of GFRP and steel beams (either simple or continuous beam) were calculated in accordance to the provisions of $\mathrm{ACl}$ 440.1R-15 [1] and ACl 318-14 [30], respectively. The theoretical moment capacities of hybrid beams were calculated based on the strain compatibility and force equilibrium. The iterative procedure involves selecting an assumed depth of the neutral axis $x$; calculating the strain level in each material using strain compatibility; calculating the associated stress level in each material (See Appendix B for the constitutive material models considered); and checking internal force equilibrium as shown in Fig 14. If the internal force resultants do not equilibrate, the depth to the neutral axis should be revised and the procedure repeated. The ultimate moment $M$ was, therefore, determined by taking moments of internal forces at equilibrium about bottom steel reinforcements using Eq (1)

$M=\sum_{i=1}^{n_{c}} C_{c i} L_{c i}+T_{f}^{\prime}\left(d_{s}-d_{f}^{\prime}\right)+T_{s}^{\prime}\left(d_{s}-d_{s}^{\prime}\right)-\sum_{j=1}^{n_{t}} C_{t j} L_{t j}-A_{f} f_{f}\left(d_{f}-d_{s}\right)$

where $L_{c i}$ and $L_{t j}$ are the lever arm for the concrete compressive and tensile forces in segment $i$ and $j$, respectively; $C_{c i}$ and $C_{t j}$ are the compressive and 
tensile forces in segment $i$ and $j$, respectively., as shown in Figure 14 (c); $T_{f}$, $T_{S}, T_{f}^{\prime}$ and $T_{s}^{\prime}$ are the forces of bottom FRP and steel bars and top FRP and steel bars, respectively; $n_{c}$ and $n_{t}$ are the number of concrete segments in compression and tension, respectively; $A_{f}, A_{s}, A_{f}^{\prime}$ and $A_{s}^{\prime}$ are the areas of tensile FRP and steel and compressive FRP and steel reinforcements, respectively; $d_{s}, d_{f}, d_{f}^{\prime}$ and $d_{s}^{\prime}$ are the depth of steel bars, GFRP bars, compression FRP bars and compression steel reinforcement.

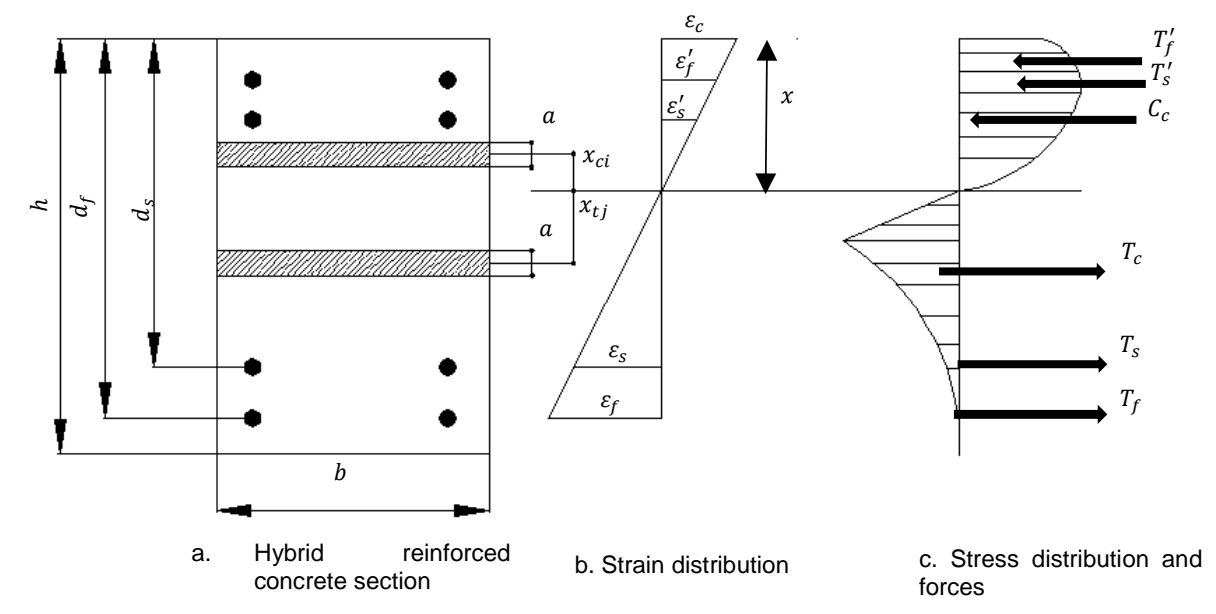

Figure 14. Strain, stresses and forces of a reinforced concrete section

Tables $4 \mathrm{a}$ and $4 \mathrm{~b}$ present the experimental and predicted moment capacities for simply supported and continuous beams, respectively. The experimental failure moments at mid-span and middle support regions are calculated from the measured end support reaction and mid-span point load at failure of each beam.

It can be seen from Tables $4 a$ and $4 b$ that the $A C l$ 440.1R-15 equation reasonably predicted the failure moments of beams S-G-1 at mid-span and beam C-G-1 at mid-span and over middle support, respectively. As for hybrid simply supported and continuous concrete beams, the predicted results for 
sagging and hogging moments at failure are in a good agreement with the experimental results.

Table 4a. Comparison between experimental and predicted results (Simply supported beams)

\begin{tabular}{cccc}
\hline \multirow{2}{*}{ Beam notation } & $\begin{array}{c}\text { Experimental results } \\
\text { Failure }\end{array}$ & $\begin{array}{c}\text { Predicted results } \\
\text { Failure }\end{array}$ & $\begin{array}{c}M_{\text {exp }} \\
\text { moments, } M_{\text {exp }}(k N . m)\end{array}$ \\
\hline S-G-1 & 77.00 & $70.00^{\mathrm{a}}$ & $M_{\text {pre }}$ \\
S-H-1 & 62.00 & 61.90 & 1.10 \\
S-H-2 & 110.00 & 99.00 & 1.00 \\
\hline Average & & & 1.10 \\
\hline Standard deviation & & & 1.06 \\
\hline
\end{tabular}

a Result obtained by ACl 440.1R.15 [1]

Table 4b. Comparison between experimental and predicted results (continuous beams)

\begin{tabular}{|c|c|c|c|c|c|c|}
\hline \multirow[t]{2}{*}{ Beam notation } & \multicolumn{2}{|c|}{$\begin{array}{l}\text { Experimental results } \\
\text { Failure } \\
\text { moments, } M_{\exp }(k N . m)\end{array}$} & \multicolumn{2}{|c|}{$\begin{array}{c}\text { Predicted results } \\
\text { Failure } \\
\text { moments, } M_{\text {pre }}(k N . m) \\
\end{array}$} & \multicolumn{2}{|c|}{$\frac{M_{\text {exp }}}{M_{\text {pre }}}$} \\
\hline & Sagging & Hogging & Sagging & Hogging & Sagging & Hogging \\
\hline C-S-1 & 97.30 & 137.00 & $85.00^{a}$ & $85.00^{a}$ & 1.14 & 1.60 \\
\hline C-G-1 & 65.60 & 69.00 & $61.00^{\mathrm{b}}$ & $61.00^{\mathrm{b}}$ & 1.08 & 1.13 \\
\hline $\mathrm{C}-\mathrm{H}-1$ & 92.00 & 118.00 & 88.00 & 117.00 & 1.04 & 1.00 \\
\hline $\mathrm{C}-\mathrm{H}-2$ & 112.00 & 146.00 & 105.00 & 152.00 & 1.06 & 0.96 \\
\hline $\mathrm{C}-\mathrm{H}-3$ & 125.00 & 132.00 & 128.00 & 130.00 & 0.98 & 1.01 \\
\hline $\mathrm{C}-\mathrm{H}-4$ & 128.00 & 174.00 & 143.00 & 160.00 & 0.90 & 1.08 \\
\hline $\mathrm{C}-\mathrm{H}-5$ & 160.00 & 186.00 & 169.00 & 172.00 & 0.95 & 1.08 \\
\hline Average & & & & & 1.02 & 1.13 \\
\hline Standard deviation & & & & & $8.00 \%$ & $22.00 \%$ \\
\hline
\end{tabular}

The predicted total failure load $P_{\text {pre }}$ of the simply supported beams is calculated from the load that causes achievement of the moment capacity at mid-span section $\left(P_{\text {pre }}=\frac{4}{L} M_{u s}\right)$. While the predicted failure load $P_{\text {pre }}$ of the continuous concrete beams would be obtained as explained below:

- For a fully ductile beam, the flexural load capacity is based on a collapse mechanism with plastic hinges at mid-span and central support sections. Thus, the flexural load capacity $P_{\text {pre }}$ on each span would be calculated from:

$$
P_{\text {pre }}=\frac{2}{L}\left(M_{u h}+2 M_{u s}\right)
$$


where $M_{u h}$ and $M_{u s}$ are the hogging and sagging moment capacities, respectively, and $L$ is the span length of concrete member.

- For a brittle elastic material, the flexural load capacity $P_{\text {pre }}$ on each span is the smaller load that causes achievement of the moment capacity at either middle support $\left(P_{\text {pre }}=M_{u h} / 0.188 \mathrm{~L}\right)$ or mid-span $\left(P_{\text {pre }}=M_{u s} / 0.156 L\right)$ section as shown in Fig. 15. It is to be noted that the above bending moment values are calculated based on a uniform flexural stiffness along the beam span.

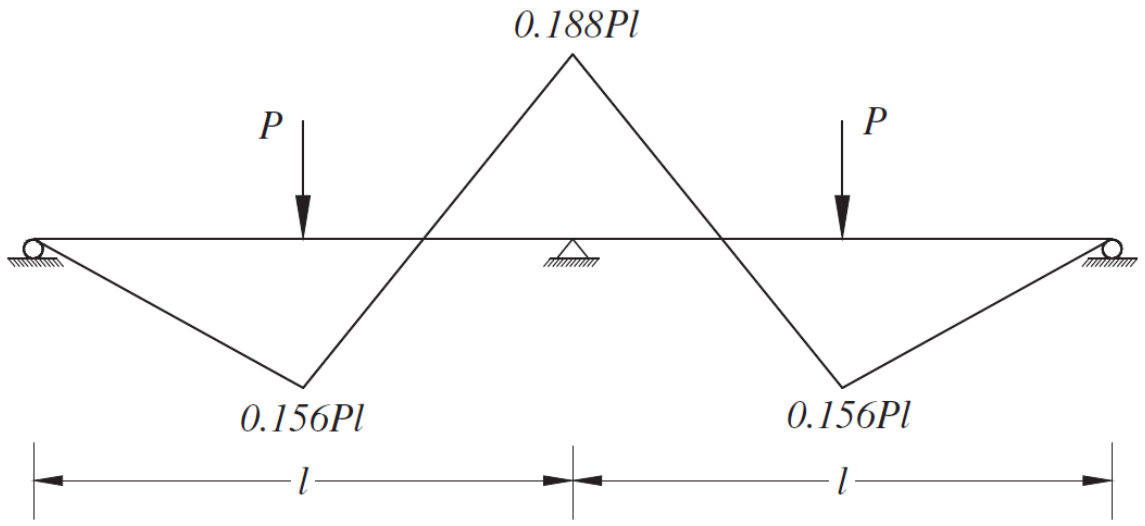

Figure 15. Elastic bending moment redistribution assuming constant flexural stiffness

Table 5a. Experimental and predicted failure loads of the tested continuous beams

\begin{tabular}{cccccc}
\hline \multirow{2}{*}{ Beam notation } & \multirow{2}{*}{$\begin{array}{c}\text { Experimental } \\
\text { Failure load } 2 P_{\text {exp }}:(k N)\end{array}$} & \multicolumn{2}{c}{ Pailure load, $2 P_{\text {pre }}:(k N)$} & \multicolumn{2}{c}{$\frac{P_{\text {exp }}}{P_{\text {pre }}}$} \\
\cline { 3 - 6 } & 465 & $2 P_{f d}$ & $2 P_{\text {bem }}$ & $P_{\text {exp }} / P_{f d}$ & $P_{\text {exp }} / P_{\text {bem }}$ \\
\hline C-H-1 & 571 & 451 & 434 & 1.03 & 1.07 \\
C-H-2 & 589 & 557 & 518 & 1.03 & 1.10 \\
C-H-3 & 665 & 594 & 532 & 0.99 & 1.11 \\
C-H-4 & 781 & 686 & 655 & 0.97 & 1.02 \\
C-H-5 & 785 & 704 & 1.00 & 1.11 \\
\hline Average & & & & 1.00 & 1.08 \\
\hline Standard deviation & & & & & \\
\hline
\end{tabular}

$\overline{P_{f d}}$ and $P_{b e m}$ are the predicted failure loads based on fully ductile and brittle elastic materials, respectively. 
Table 5b. Experimental and predicted failure loads of the tested simply supported beams

\begin{tabular}{cccc}
\hline \multirow{2}{*}{ Beam notation } & $\begin{array}{c}\text { Experimental } \\
\text { Failure load } P_{\text {exp }}:(k N)\end{array}$ & $\begin{array}{c}\text { Predicted } \\
\text { Failure load, } P_{\text {pre }}:(k N)\end{array}$ & $\begin{array}{c}P_{\text {exp }} \\
P_{\text {pre }}\end{array}$ \\
\hline S-H-1 & 94 & $95^{\mathrm{a}}$ & 0.99 \\
$\mathrm{~S}-\mathrm{H}-2$ & 169 & $152^{\mathrm{a}}$ & 1.11 \\
\hline Average & & & 1.05 \\
\hline \multicolumn{2}{l}{ Standard deviation } & & $8.50 \%$ \\
\hline
\end{tabular}

${ }^{\text {a }} P_{\text {pre }}=\frac{4}{L} M_{\text {us }}$.

Tables 5.a and5.b present the experimental against theoretical failure loads for hybrid reinforced concrete continuous beams based on the above two assumptions and hybrid simply supported beams, respectively. As shown in Table 5.a, the predicted failure load obtained from Eq. (2) based on the moment capacities at mid-span and middle support sections gives the closest results for all beams with an average and standard deviation between the experimental and predicted load capacities $1.0 \%$ and $2.5 \%$, respectively. On the other hand, the predicted failure load calculated based on brittle material slightly underestimated the experimental failure load with an average and standard deviation between the experimental and predicted load capacities of $1.08 \%$ and $3.90 \%$, respectively. Predictions of the load capacities of the two simply supported beams $\mathrm{S}-\mathrm{H}-1$ and $\mathrm{S}-\mathrm{H}-2$ are reasonably predicted by current model which employed to predict moments (see Table 5b).

\section{Mid-span deflection predictions}

The immediate deflection $\Delta$ of continuous and simply supported reinforced concrete beams loaded with a mid-span point load illustrated in Figs 1 and 2, respectively, could be calculated by Eqs. (3) and (4), respectively, as given below:

$\Delta=\frac{7}{768} \frac{P l^{3}}{E_{c} I_{e}}$ 
$\Delta=\frac{P l^{3}}{48 E_{c} I_{e}}$

where $P$ is the mid-span applied load at which the deflection is computed, $l$ is the span length, $E_{c}$ is the modulus of elasticity of concrete and $I_{e}$ is the effective moment of inertia of the beam section. An expression for the effective moment of inertia $I_{e}$ to be used for predicting the deflection of FRP reinforced concrete beams is given by $\mathrm{ACl} 440.1 \mathrm{R}-15$ [1] as follows

$$
I_{e}=\frac{I_{c r}}{1-\gamma\left(\frac{M_{c r}}{M_{a}}\right)^{2}\left[1-\frac{I_{c r}}{I g}\right]} \leq I_{g}
$$

where $M_{c r}$ is the cracking moment $=2 \frac{f_{c r} I_{g}}{h}, M_{a}$ is the applied moment, $\gamma$ is a factor which accounts for the length of the uncracked regions of the member and for the change in stiffness in the cracked regions $=1.72-0.72\left(\frac{M_{c r}}{M_{a}}\right) . I_{g}$ is the gross moment of inertia $=\frac{b h^{3}}{12}, b$ and $h$ are the width and overall height of the concrete beam, respectively, $I_{c r}$ is the moment of inertia of transformed cracked section $=\frac{b d^{3}}{3} k^{3}+\left(n_{f} A_{f}\right) d^{2}(1-k)^{2}, k$ is the ratio of the neutral axis depth to reinforcement depth $=\sqrt{\left(\rho_{f} n_{f}\right)^{2}+2 \rho_{f} n_{f}}-\rho_{f} n_{f}, n_{f}\left(=\frac{E_{f}}{E_{c}}\right)$ is the modulus ratio between FRP reinforcement and concrete, $E_{c}\left(=4750 \sqrt{f_{c}^{\prime}}\right)$ is the concrete modulus of elasticity and $f_{c r}\left(=0.62 \sqrt{f_{c}^{\prime}}\right)$ is the modulus of rupture of concrete. The use of Eq. (5) to predict the continuous change in flexural stiffness in the cracked regions of hybrid GFRP/steel beams is inappropriate, as it does not take into account the change of curve slope after yielding of steel.

To adopt the $\mathrm{ACl} 440.1 \mathrm{R}-15$ equation for predicting the deflection of hybrid GFRP/steel reinforced concrete beams, the effect of steel reinforcement should be taken into account. Therefore, the following equation for $I_{c r}$ of hybrid GFRP and steel reinforced concrete beams is used. 


$$
\begin{aligned}
& I_{c r}=\frac{b d^{3}}{3} k^{3}+\left(n_{f} A_{f}+n_{s} A_{s}\right) d^{2}(1-k)^{2} \\
& k=\sqrt{\left(\rho^{\prime}\right)^{2}+2 \rho^{\prime}}-\rho^{\prime} \\
& \rho^{\prime}=\rho_{f} n_{f}+\rho_{s} n_{s}
\end{aligned}
$$

where $n_{s}\left(=\frac{E_{s}}{E_{c}}\right)$ is the elastic modulus ratio between steel reinforcement and concrete and $d$ is the distance from extreme compression fiber to the centroid of the tension reinforcing zone.

More precisely, Yoon et al [23] proposed an expression for the effective moment of inertia $I_{e}$, which is based on Bischoff's approach, to be used for predicting the deflection of hybrid sections as in Eq (9) below:

$$
\begin{aligned}
& I_{e}=\frac{I_{c r 1}}{\frac{I_{c r 1}}{I_{c r 2}}+\frac{M_{y}}{M_{a}}\left(1-\frac{I_{c r 1}}{I_{c r 2}}\right)-\left(\frac{M_{y}}{M_{a}}\right)^{2}\left(1-\frac{I_{c r 1}}{I_{c r 2}}\right)} \leq I_{g} \\
& I_{c r 1}\left(=\frac{b d^{3}}{3} k_{1}^{3}+\left(n_{f} A_{f}\right) d^{2}\left(1-k_{1}\right)^{2}\right)+\left(n_{S} A_{S}\right) d^{2}\left(1-k_{1}\right)^{2} \\
& k_{1}\left(=\sqrt{\left[\rho_{f} n_{f}+\rho_{s} n_{s}\left(\frac{d_{s}}{d_{f}}\right)\right]^{2}+2\left[\rho_{f} n_{f}+\rho_{s} n_{s}\left(\frac{d_{s}}{d_{f}}\right)^{2}\right]}-\left[\rho_{f} n_{f}+\rho_{s} n_{s}\left(\frac{d_{s}}{d_{f}}\right)\right]\right.
\end{aligned}
$$

where $M_{y}$ is the steel yielding moment, $I_{c r 1}$ is the moment of inertia of transformed cracked hybrid section, $k_{1}$ is the ratio of the neutral axis depth to reinforcement depth before steel yields, $d_{s}, d_{f}$ is the distance between extreme fiber of concrete in compression and steel and GFRP bars, respectively, $I_{c r 2}$ (= $\left.\frac{b d^{3}}{3} k^{3}+\left(n_{f} A_{f}\right) d^{2}(1-k)^{2}\right)$ is the transformed cracked moment of inertia after steel yields.

The comparisons between the experimental and theoretical load-deflection diagrams for the tested beams are shown in Fig 16. The comparison is made between the experimental results and the predictions obtained by ACl 440.1R15 for FRP beams and hybrid beams, and Yoon's model for hybrid beams. The prediction process has shown a good agreement for beam S-G-1 whereas a 
stiffer trend for beam $\mathrm{C}-\mathrm{G}-1$ is predicted by $\mathrm{ACl} 440.1 \mathrm{R}-15$ [1] equation as presented in Figs 16-A and 16-B, respectively.

As for hybrid simply supported concrete beams $\mathrm{S}-\mathrm{H}-1$ and $\mathrm{S}-\mathrm{H}-2$, the curves show that there is a good agreement between the experimental results and predicted deflections values by Yoon's model as shown in Figs 16-C and 16$D$, respectively. On the other hand, it was clear that ACI.440.1R-15 [1] equation underestimated the deflections at all stages of loading after cracking. As load increased, this underestimation has progressively increased until failure as ACl.440.1R-15 [1] equation does not take into account post yielding of steel. Yoon's model for hybrid continuous concrete beams $\mathrm{C}-\mathrm{H}-1$ and $\mathrm{C}-\mathrm{H}-2$ has given a closer deflection to experimentally measured deflections for the applied loads up to failure as shown in Figs 16-E and 16-F. As the steel reinforcement ratio increased (beam $\mathrm{C}-\mathrm{H}-3$ ), Yoon's equation tended to overestimate the mid-span deflections at higher service loads as shown in Fig 16-G. It can be seen from Fig $16-\mathrm{H}$ that Yoon's model predicted the deflections of beam $\mathrm{C}-\mathrm{H}-4$ with a steady overestimation of deflections after cracking. On the other hand, it predicted the deflection of beam $\mathrm{C}-\mathrm{H}-5$ with a steady underestimation of the deflection as shown in Fig 16-I. This might be attributed to the high ratio of GFRP to steel bars in beams $\mathrm{C}-\mathrm{H}-4$ and $\mathrm{C}-\mathrm{H}-5$. 

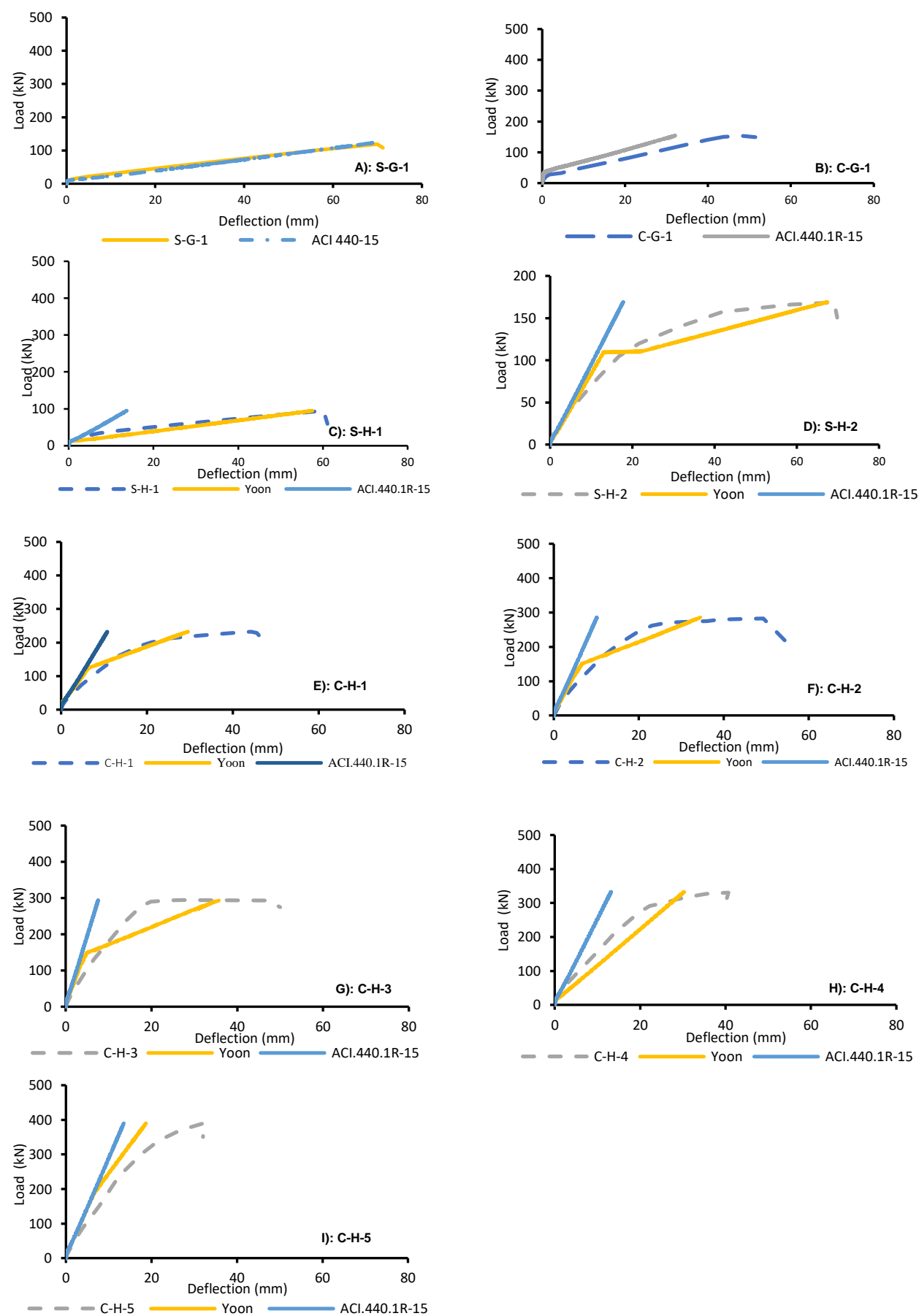

Figure 16. Experimental and predicted deflections for beams tested 


\section{Conclusions}

The results of seven continuous concrete beams reinforced with either steel, GFRP or hybrid GFRP/steel bars have been presented. The following conclusions are drawn:

Unlike GFRP reinforced concrete beams, the hybrid and steel reinforced concrete beams failed in a favourable ductile manner due to concrete crushing after yielding of steel reinforcement.

The lower stiffness, higher deflection and wider cracks of GFRP reinforced concrete beams can be controlled and improved by the use of steel reinforcement in combination with GFRP re-bars.

The ratio of GFRP to steel reinforcement is a key factor to ensure sufficient ductility and stiffness beyond the first cracking stage. Therefore, hybrid reinforced beams should be designed based on yielding of steel reinforcement prior to crushing of concrete or FRP rupture.

The stiffness of hybrid beams increased with either the increase of steel or GFRP reinforcement after the first cracking. However, increasing the amount of steel bars resulted in less load capacity increase after yielding of steel, whereas less ductile behaviour would be achieved by increasing the amount of GFRP bars.

The moment- carrying capacity is more influenced by the hybrid reinforcement ratio than the axial stiffness ratio. Increasing the axial stiffness is not proportional with moment capacity increase.

The serviceability limit state could be achieved by using hybrid reinforcement method in which a small amount of GFRP bars would be required in comparison with using only GFRP bars as internal reinforcing bars. This would 
result in less reinforcement ratio especially at joints where multi-span continuous beams supported over columns, which in return less congestion. The developed technique provided a reasonable predication for the sagging moment capacity of the tested beams. The ratio of the experimental to predicted moment capacity is, on average, 1.02 with a standard deviation of $8 \%$ for sagging regions and 1.13 and $22 \%$ for hogging regions.

The ACI.440.1R-15 equation underestimated the deflections of hybrid beams at all stages of loading after cracking, whereas Yoon's model seems to provide reasonable trend compared with experimental mid-span deflections of hybrid continuous concrete beams. 


\section{APPENDIX A}

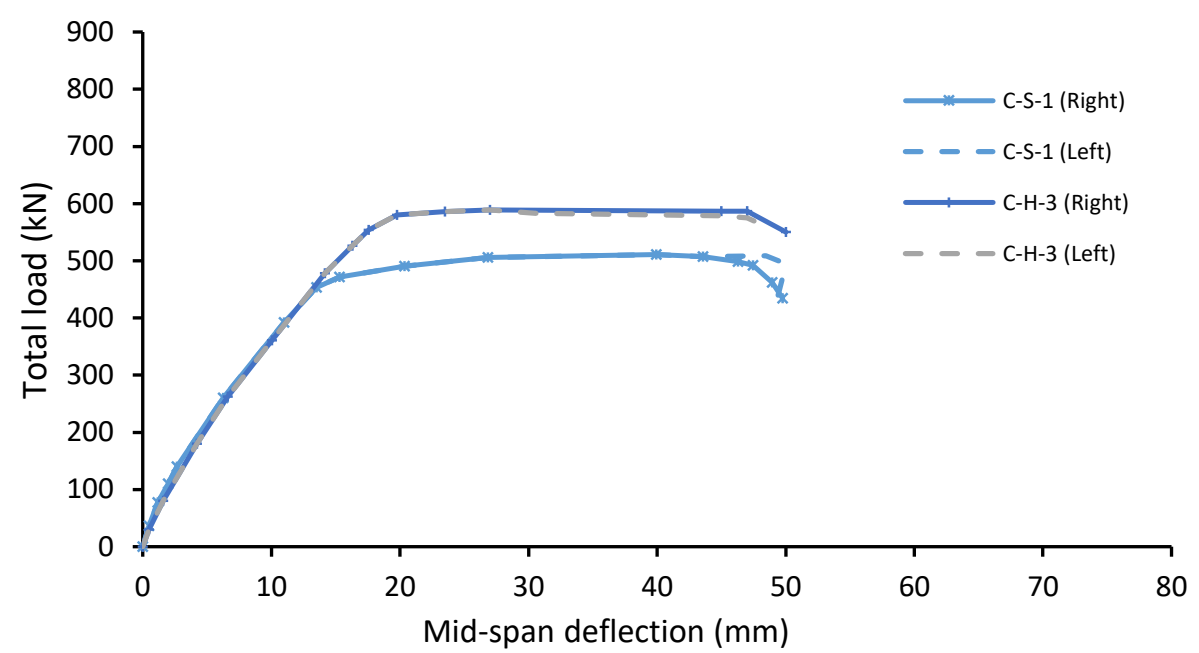

Figure A. 1. Load deflection relationships for the two mid-spans of beams C$\mathrm{S}-1$ and $\mathrm{C}-\mathrm{H}-3$

Figure A.1 shows the load-deflection relationship for the two mid-spans of two beams (C-S-1 and $\mathrm{C}-\mathrm{H}-3)$, confirming the symmetrical behaviour about the middle support up until almost the beam failure.

\section{APPENDIX B}

The stress-strain relationships of concrete, steel and FRP reinforcements are shown in Fig. B.1. These models can be represented by the following equations:

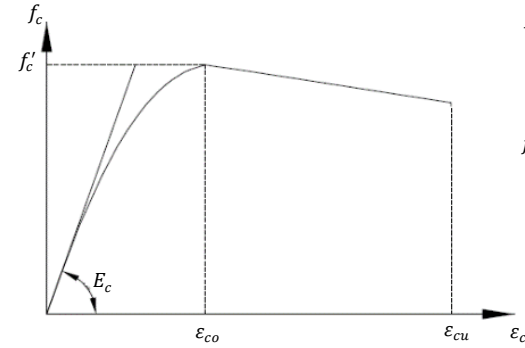

(a) Concrete in compression

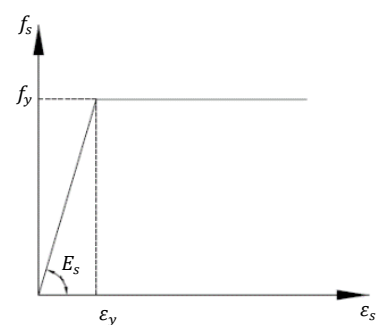

(c)

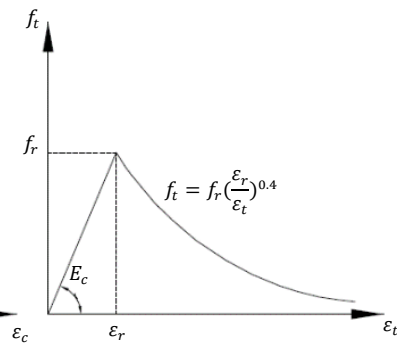

(b) Concrete in tension

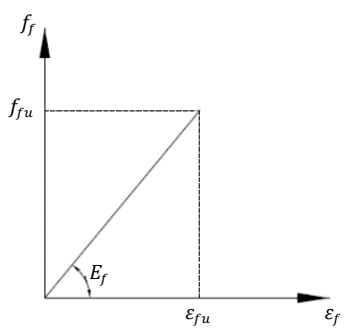

(d) FRP 
Figure B. 1. FRP, steel and concrete stress-strain relationships.

\section{Concrete in Compression}

The uniaxial stress-strain relationship of concrete in compression shown in Figure B. 1(a) developed by Hognestad [32], is adopted in the current investigation. The equations for different parts of the relationship are as follows:

$f_{c}=f_{c}^{\prime}\left[2 \frac{\varepsilon_{c}}{\varepsilon_{c o}}-\left(\frac{\varepsilon_{c}}{\varepsilon_{c o}}\right)^{2}\right] \quad 0 \leq \varepsilon_{c} \leq \varepsilon_{c o}$

$f_{c}=f_{c}^{\prime}\left[1-0.15\left(\frac{\varepsilon_{c}-\varepsilon_{c o}}{\varepsilon_{c u}-\varepsilon_{c o}}\right)\right] \quad \varepsilon_{c o}<\varepsilon_{c} \leq \varepsilon_{c u}$

where $f_{c}$ and $\varepsilon_{c}$ are the stress and the strain in compressive concrete, respectively, $f_{c}^{\prime}$ is the cylinder compressive strength of concrete, $\varepsilon_{c o}=2.4 \times$ $10^{-4} \sqrt{f_{c}^{\prime}}$ is the strain of concrete corresponding to maximum stress, $E_{c}=$ $4700 \sqrt{f_{c}^{\prime}}$ is the elasticity modulus of concrete and $\varepsilon_{c u}(=0.0035)$ is the ultimate strain of concrete.

\section{Concrete in Tension}

The stress-strain relationship shown in Figure B. 1(b) is adopted in the current investigation and calculated in Eqs (B. 3) and (B. 4) respectively, as follows [33] :

$$
\begin{array}{cl}
f_{t}=E_{c} \varepsilon_{t} & 0 \leq \varepsilon_{t} \leq \varepsilon_{r} \\
f_{t}=f_{r}\left(\frac{\varepsilon_{r}}{\varepsilon_{t}}\right)^{0.4} & \varepsilon_{r} \leq \varepsilon_{t}
\end{array}
$$


where $f_{t}$ and $\varepsilon_{t}$ are the tensile stress and strain in concrete, respectively, $f_{r}\left(=0.62 \sqrt{f_{c}^{\prime}}\right)$ and $\varepsilon_{r}$ are the ultimate tensile strength and corresponding tensile strain of concrete, respectively.

\section{Steel Reinforcement}

Reinforcing steel is modelled as a bilinear elastic-perfectly plastic material with yield stress $f_{y}$ as shown in Figure B. 1(c) The equations for different parts of the relationship are:

$$
\begin{array}{ll}
f_{s}=\varepsilon_{s} E_{s} & \varepsilon_{s}<\varepsilon_{y} \\
f_{s}=f_{y} & \varepsilon_{s} \geq \varepsilon_{y}
\end{array}
$$

where $\varepsilon_{s}, f_{s}, \varepsilon_{y}, f_{y}$ and $E_{s}$ are the strain, stress, yield strain, yield stress and Young's modulus, respectively, of the steel reinforcement.

\section{FRP Reinforcement}

The stress-strain relationship of FRP bars in tension is linear elastic up to rupture as shown in Figure B. 1(d). The equations governing the relationship are as follows:

$$
\begin{array}{cc}
f_{f}=\varepsilon_{f} E_{f} & \varepsilon_{f} \leq \varepsilon_{f u} \\
f_{f}=0 & \varepsilon_{f}>\varepsilon_{f u}
\end{array}
$$

where $\varepsilon_{f}, f_{f}, \varepsilon_{f u}, f_{f u}$ and $E_{f}$ are the strain, stress, rupture strain, rupture tensile strength and Young's modulus, respectively, of the FRP reinforcement. 


\section{References}

[1] American Concrete Institute (ACl). (2015). "Guide for the Design and Construction of Concrete Reinforced with FRP Bars." ACl 440.1R-15, Farmington Hills, Mich.

[2] Habeeb, M., \& Ashour, A. F. (2008). Flexural behavior of continuous GFRP reinforced concrete beams. ASCE Journal of Composites for Construction, 12(2), 115-124.

[3] Mahroug, M., Ashour, A. F., \& Lam, D. (2014a). Experimental response and code modelling of continuous concrete slabs reinforced with BFRP bars. Composite Structures, 107, 664-674.

[4] Mahroug, M., Ashour, A. F., \& Lam, D. (2014b). Tests of continuous concrete slabs reinforced with carbon fibre reinforced polymer bars. Composites Part B: Engineering, 66, 348-357.

[5] Nanni, A., Henneke, M. J., \& Okamoto, T. (1994). Tensile properties of hybrid rods for concrete reinforcement. Construction and Building Materials, 8(1), 27-34.

[6] Tepfers, R., Tamužs, V., Apinis, R., Vilks, U. and Modniks, J., (1996).

Ductility of nonmetallic hybrid fiber composite reinforcement for concrete. Mechanics of composite materials, 32(2), pp.113-121.

[7] Somboonsong, W., Ko, F. K., \& Harris, H. G. (1998). Ductile hybrid fiber reinforced plastic reinforcing bar for concrete structures: design methodology. Materials Journal, 95(6), 655-666. 
[8] Harris, H. G., Somboonsong, W., \& Ko, F. K. (1998). New ductile hybrid FRP reinforcing bar for concrete structures. ASCE Journal of Composites for Construction, 2(1), 28-37.

[9] Saikia, B., Thomas, J., Ramaswamy, A., \& Rao, K. N. (2005). Performance of hybrid rebars as longitudinal reinforcement in normal strength concrete. Materials and structures, 38(10), 857-864.

[10] Cheung, M. M., \& Tsang, T. K. (2010). Behaviour of concrete beams reinforced with hybrid FRP composite rebar. Advances in Structural Engineering, 13(1), 81-93.

[11] Cui, Y., Cheung, M. M., Noruziaan, B., Lee, S., \& Tao, J. (2008). Development of ductile composite reinforcement bars for concrete structures. Materials and structures, 41(9), 1509-1518.

[12] Etman, E. E.-S. (2010). Innovative hybrid reinforcement for flexural members. ASCE Journal of Composites for Construction, 15(1), 2-8.

[13] Behnam, B. and Eamon, C., 2014. Analysis of alternative ductile fiberreinforced polymer reinforcing bar concepts. Journal of Composite Materials, 48(6), pp.723-733.

[14] Zhou, Y., Wu, Y., Teng, J., \& Leung, A. (2009). Ductility analysis of compression-yielding FRP-reinforced composite beams. Cement and Concrete Composites, 31(9), 682-691.

[15] Alsayed, S. H., \& Alhozaimy, A. M. (1999). Ductility of concrete beams reinforced with FRP bars and steel fibers. Journal of composite materials, 33(19), 1792-1806. 
[16] Li, V. C., \& Wang, S. (2002). Flexural behaviors of glass fiber-reinforced polymer (GFRP) reinforced engineered cementitious composite beams. Materials Journal, 99(1), 11-21.

[17] Wang, H., \& Belarbi, A. (2011). Ductility characteristics of fiberreinforced-concrete beams reinforced with FRP rebars. Construction and Building Materials, 25(5), 2391-2401.

[18] Tan, K. H. (1997) Behaviour of hybrid FRP-steel reinforced concrete beams. Proc., 3rd Int. Symp. on Non-Metallic (FRP) Reinforcement for Concrete Structures (FRPRCS-3), Japan Concrete Institute, Tokyo, 487-494.

[19] Aiello, M. A., \& Ombres, L. (2002). Structural performances of concrete beams with hybrid (fiber-reinforced polymer-steel) reinforcements. ASCE Journal of Composites for Construction, 6(2), 133-140.

[20] Leung, H., \& Balendran, R. (2003). Flexural behaviour of concrete beams internally reinforced with GFRP rods and steel rebars. Structural Survey, 21(4), 146-157.

[21] Qu, W., Zhang, X., \& Huang, H. (2009). Flexural behavior of concrete beams reinforced with hybrid (GFRP and steel) bars. ASCE Journal of Composites for Construction, 13(5), 350-359.

[22] Lau, D., \& Pam, H. J. (2010). Experimental study of hybrid FRP reinforced concrete beams. Engineering Structures, 32(12), 3857-3865. 
[23] Yoon, Y. S., Yang, J. M., Min, K. H., \& Shin, H. O. (2011). Flexural strength and deflection characteristics of high-strength concrete beams with hybrid FRP and steel bar reinforcement. Proc., 10th Int. Symp. on FiberReinforced Polymer Reinforcement for Concrete Structures (FRPRCS10), in conjunction with the ACI Spring 2011 Convention, Tampa, FL, USA, American Concrete Institute.

[24] Yinghao, L., \& Yong, Y. (2013). Arrangement of hybrid rebars on flexural behavior of HSC beams. Composites Part B: Engineering, 45(1), 22-31.

[25] Safan, M. A. (2013). Flexural Behavior and Design of Steel-GFRP Reinforced Concrete Beams. ACI Materials Journal, 110(6), 677-686.

[26] El Refai, A., Abed, F., \& Al-Rahmani, A. (2015). Structural performance and serviceability of concrete beams reinforced with hybrid (GFRP and steel) bars. Construction and Building Materials, 96, 518-529.

[27] Kara, I. F., Ashour, A. F., \& Köroğlu, M. A. (2015). Flexural behavior of hybrid FRP/steel reinforced concrete beams. Composite Structures, 129, 111-121.

[28] EL-MOGY, M., EL-RAGABY, A. \& EL-SALAKAWY, E. 2010. Flexural behavior of continuous FRP-reinforced concrete beams. ASCE Journal of Composites for Construction, 14 (6), 669-680.

[29] American Concrete Institute (ACI). (2004). "Guide test methods for fiber reinforced polymer FRPs for reinforcing or strengthening concrete structures." ACl 440.3R-04, Farmington Hills, Mich. 
[30] American Concrete Institute (ACI). (2014). "Building code requirements for structural concrete and commentary." $\mathrm{ACl} 318 \mathrm{M}-14$, Farmington Hills, Mich.

[31] Canadian Standards Association (CSA). (2012). "Design and construction of building components with fibre-reinforced polymers." CSA Standard S806-12, Rexdale, Ont., Canada.

[32] Hognestad, E., Hanson, N. W. \& Mchenry, D., 1955 Concrete stress distribution in ultimate strength design. ACI Journal Proceedings, 52(12). $455-480$

[33] BELARBI, A. \& HSU, T. T. 1994. Constitutive laws of concrete in tension and reinforcing bars stiffened by concrete. Structural Journal, 91(4), 465-474. 